Fall 1942

\title{
1942 Cedrus Yearbook
}

\section{Cedarville College}

Follow this and additional works at: https://digitalcommons.cedarville.edu/yearbooks

Part of the Higher Education Commons, Organizational Communication Commons, and the Public Relations and Advertising Commons

\section{Recommended Citation}

Cedarville College, "1942 Cedrus Yearbook" (1942). Yearbooks. 67.

https://digitalcommons.cedarville.edu/yearbooks/67

This Book is brought to you for free and open access by DigitalCommons@Cedarville, a service of the Centennial Library. It has been accepted for inclusion in Yearbooks by an authorized administrator of DigitalCommons@Cedarville. For more information, please contact digitalcommons@cedarville.edu. 

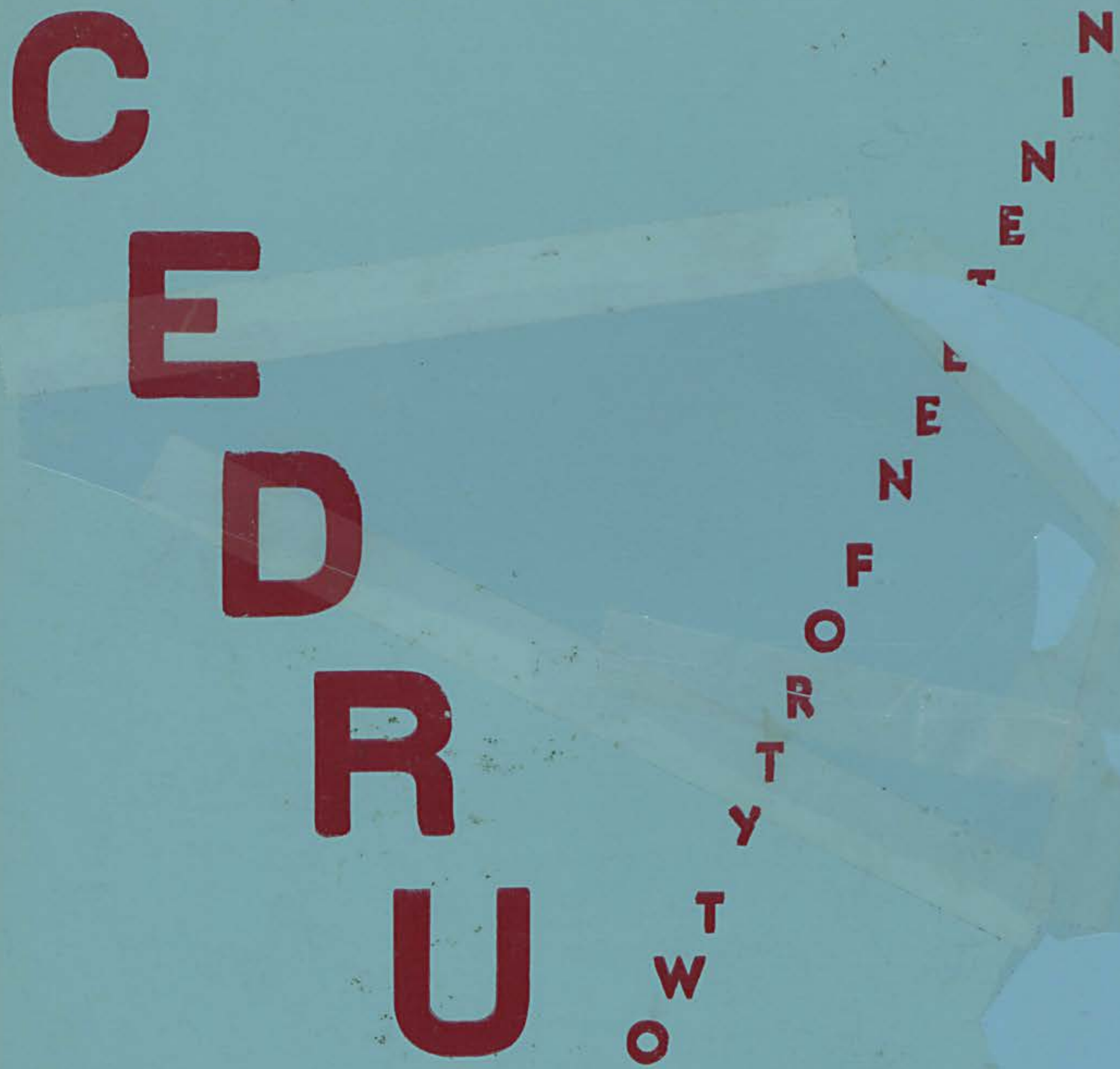
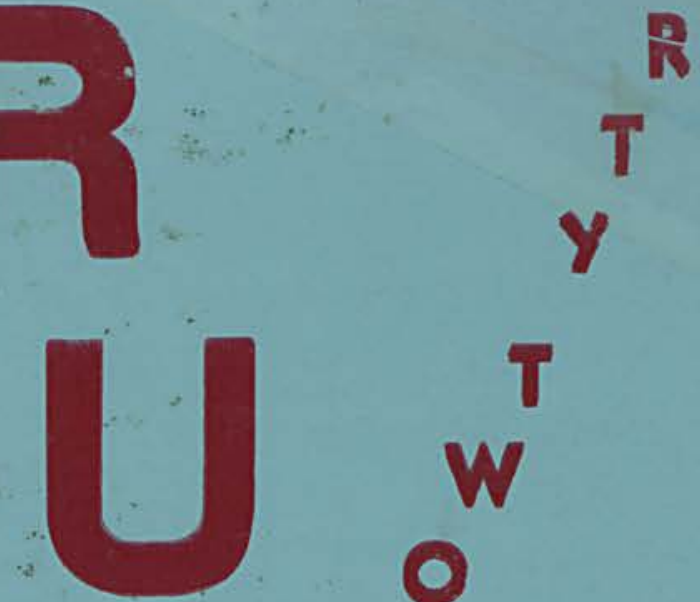

○

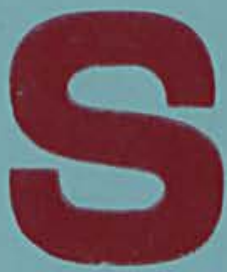




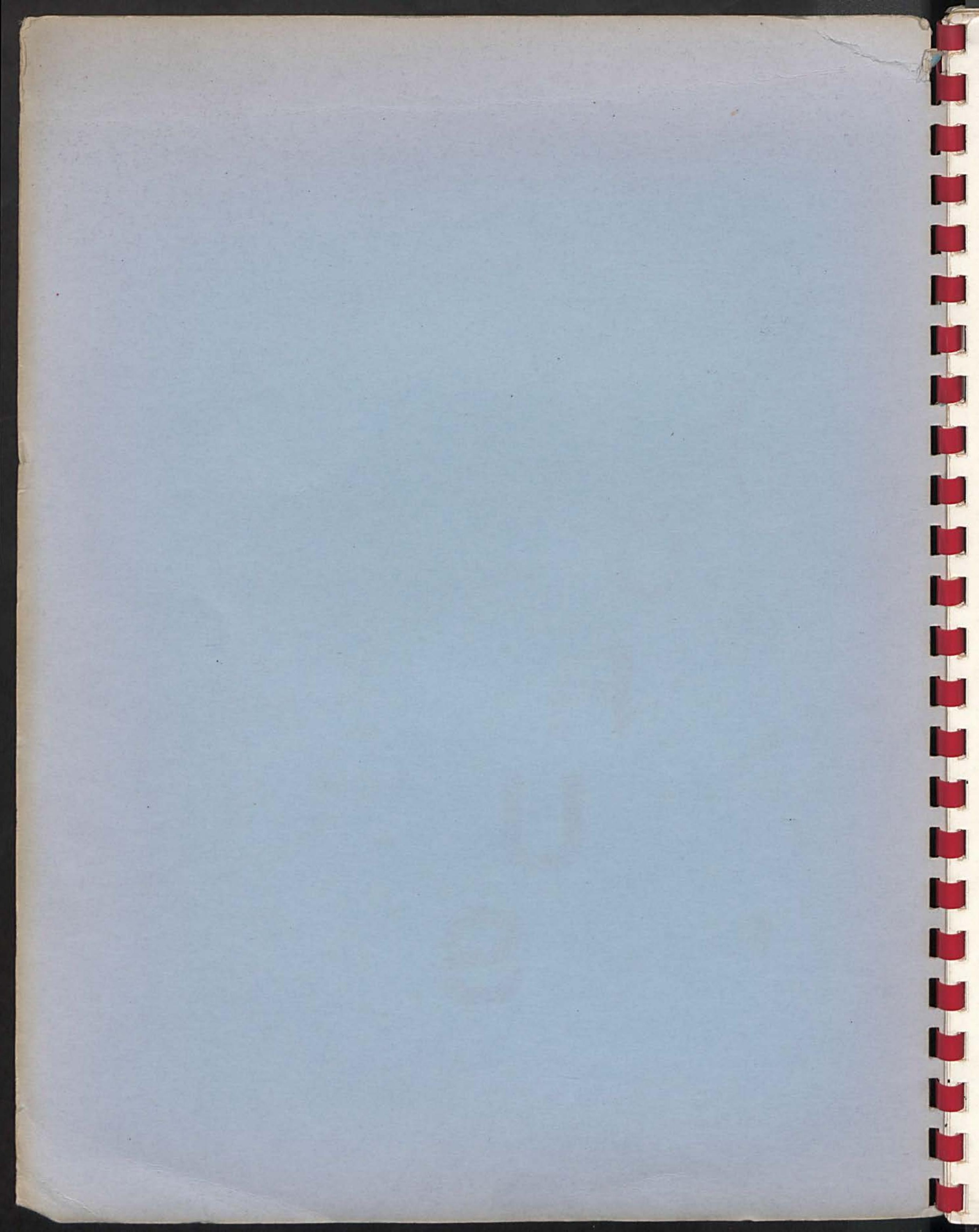




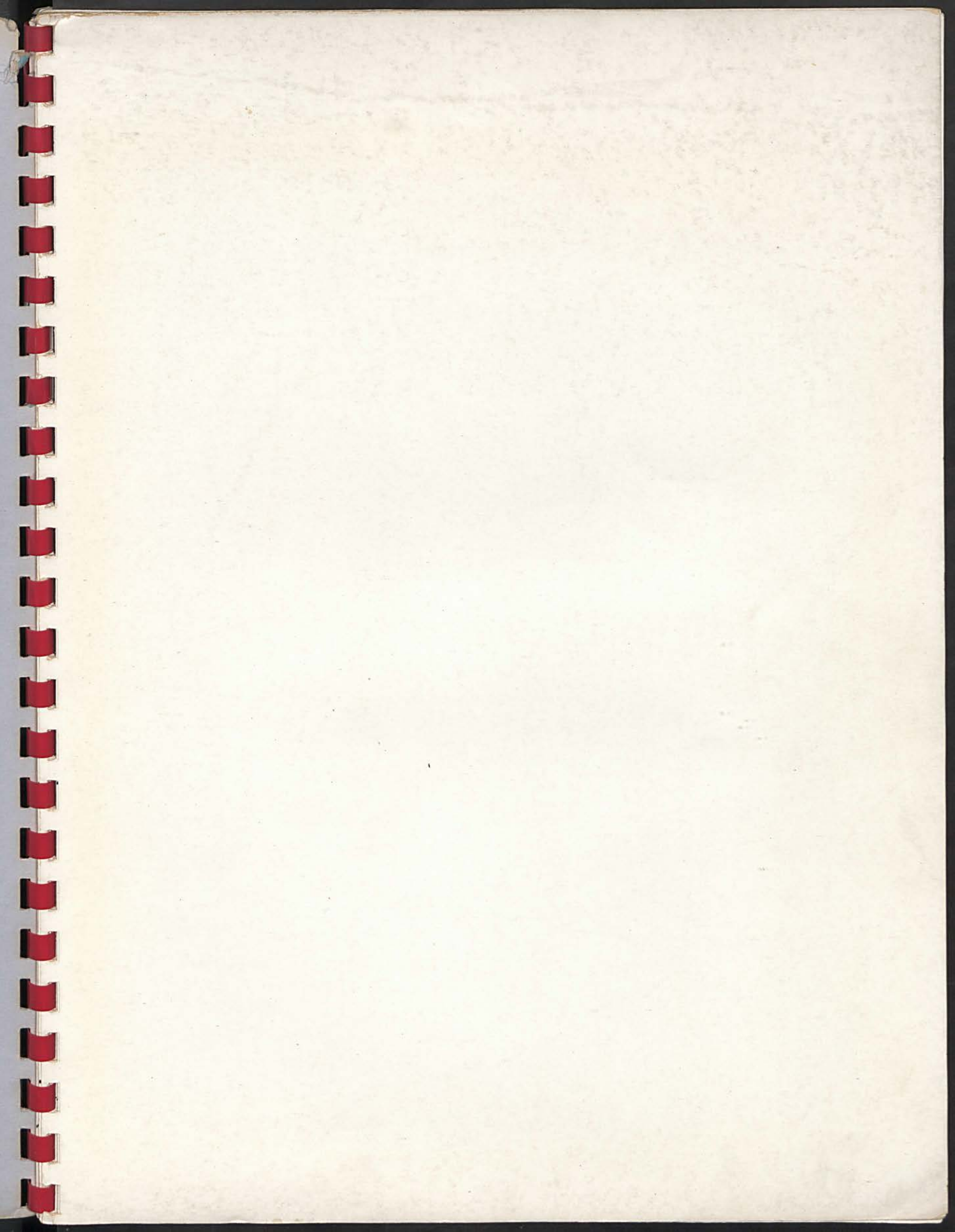





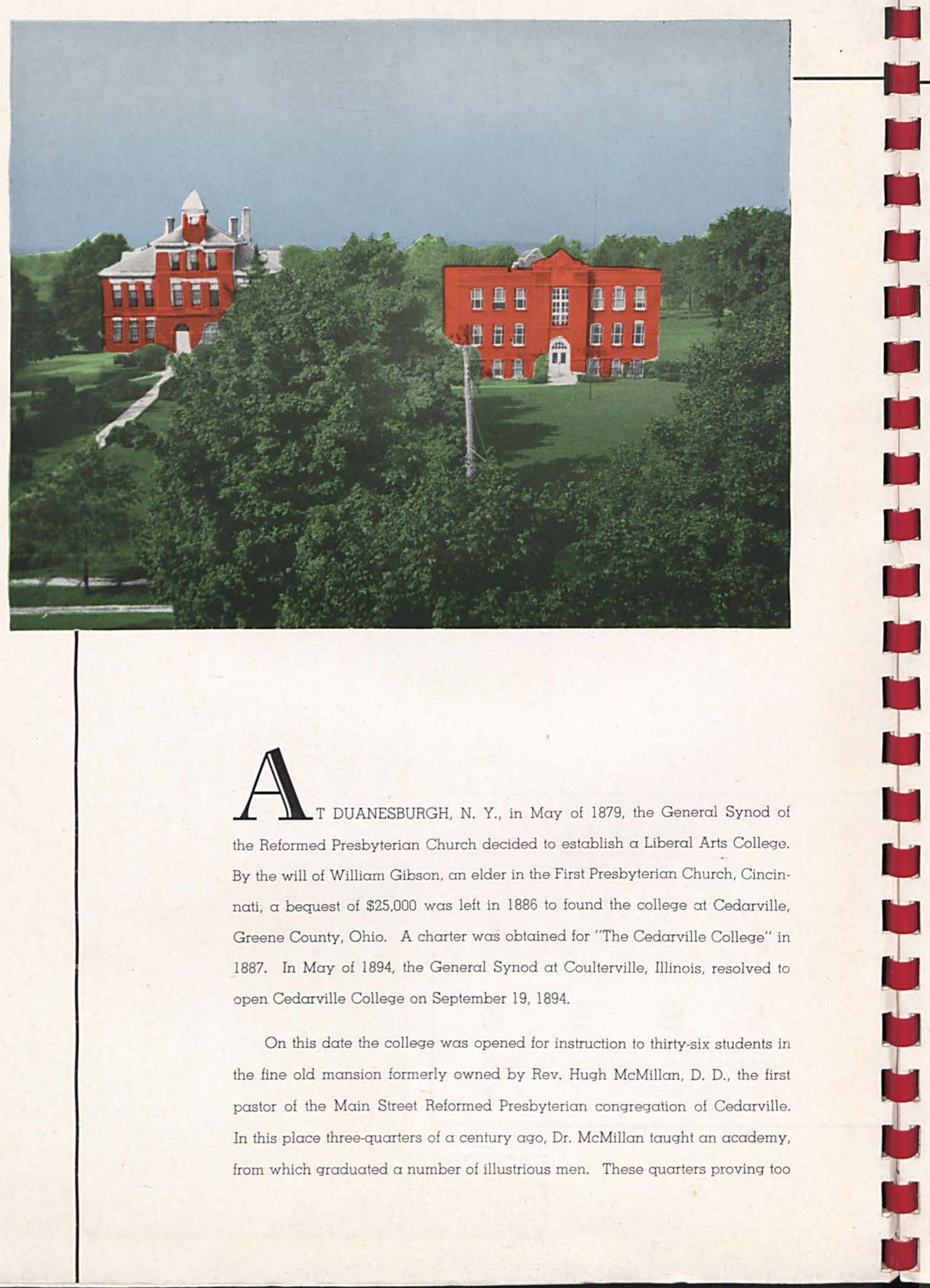




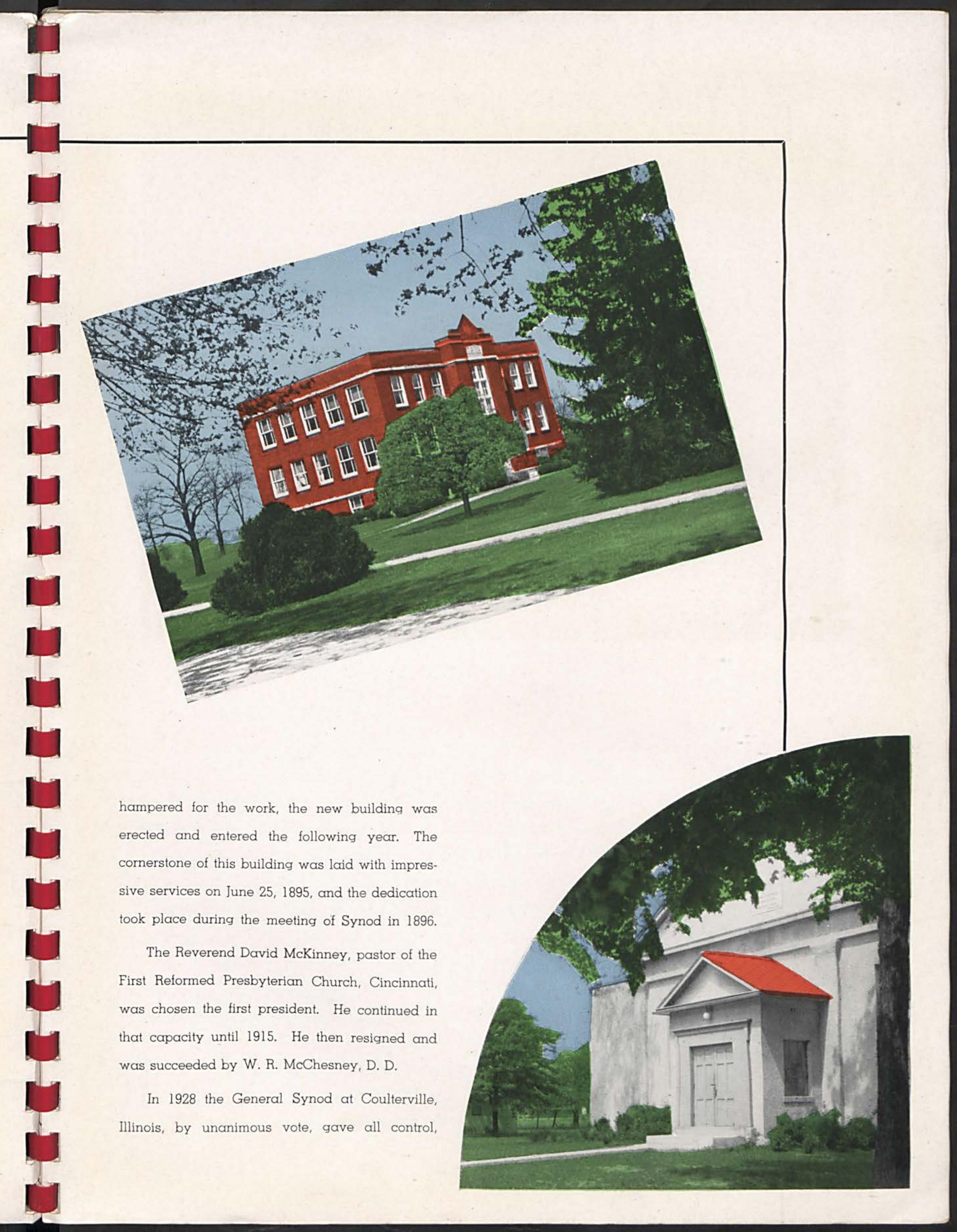




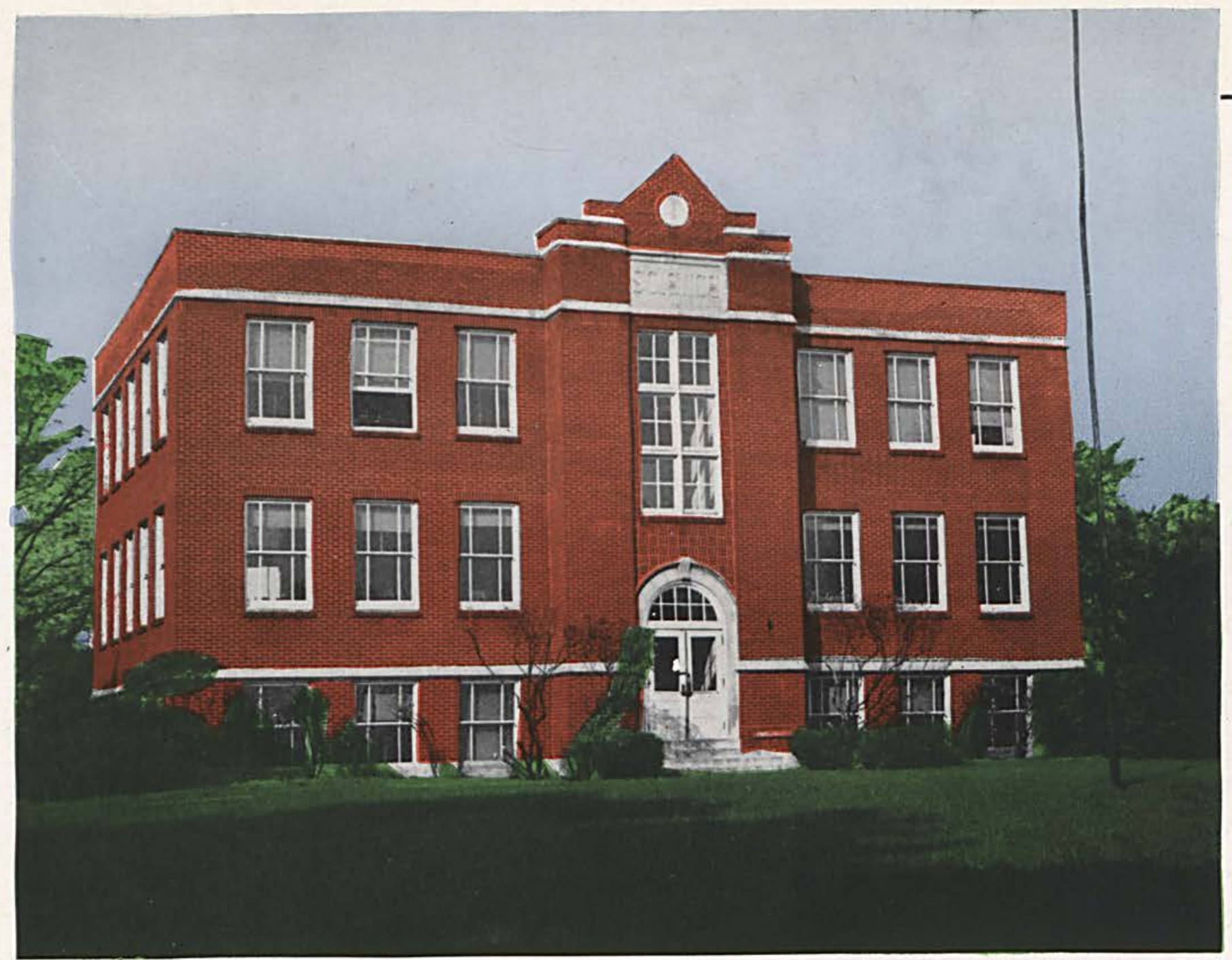

ownership, title, and vested property rights of Cedarville College to the Board of Trustees of Cedarville College and their successors forever. Since 1928, the Board of Trustees, composed for the most part of Presbyterians, have had full control and management of Cedarville College.

In June, 1939, President McChesney asked to be relieved of his administrative duties by or before July, 1941. In accordance with this wish, the Board secured the Rev. Walter S. Kilpatrick, of the class of 1934, as president-elect. His inauguration as third president of Cedarville College took place October 4, 1940.

In 1913 the Theological Seminary of the Reformed Presbyterian Church was moved to Cedarville, where for over $\alpha$ quarter of a century it has operated in close cooperation with the college.

During the forty-six years of its history Cedarville College has drawn to its halls students from all parts of the United States and other parts of the world. 


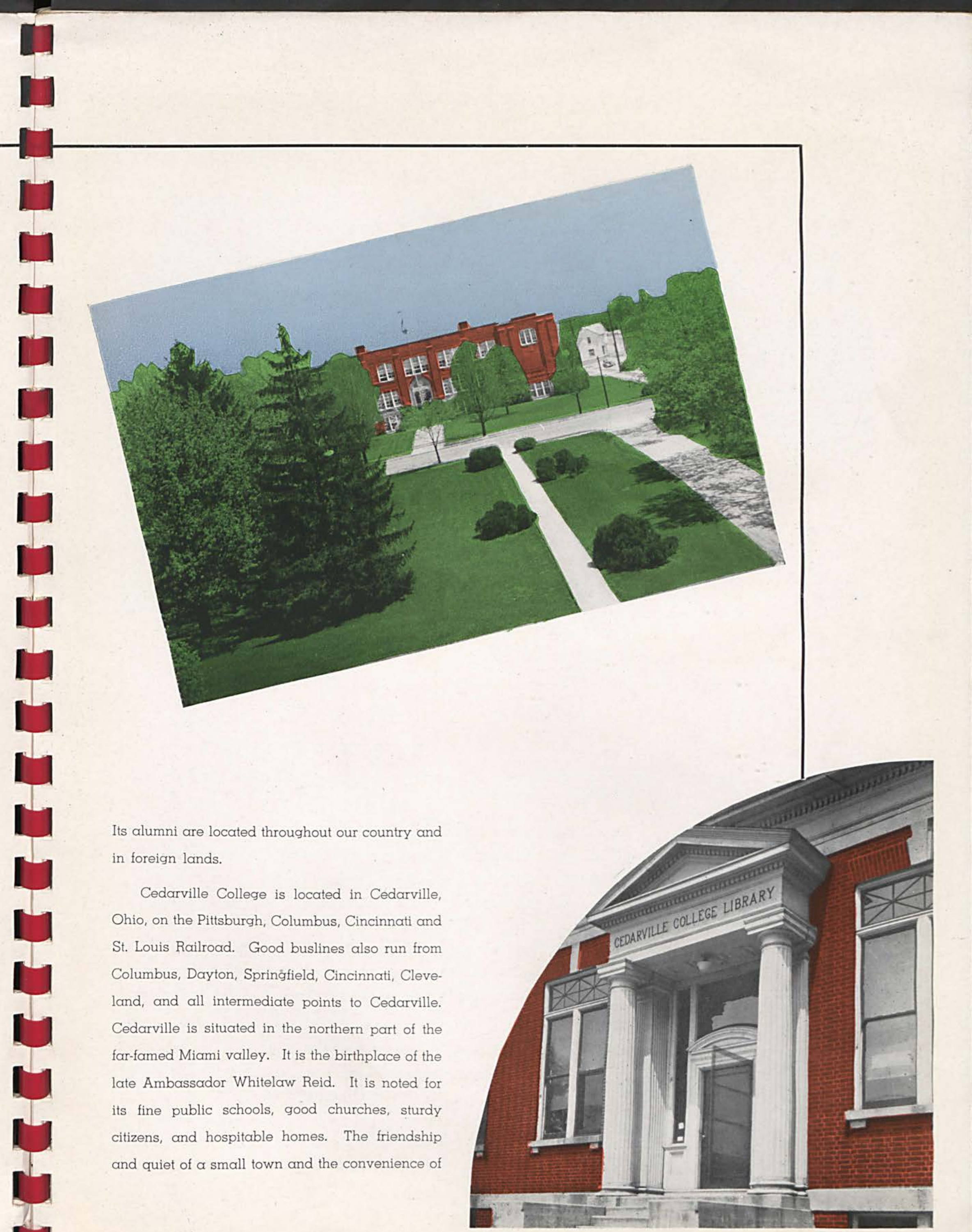




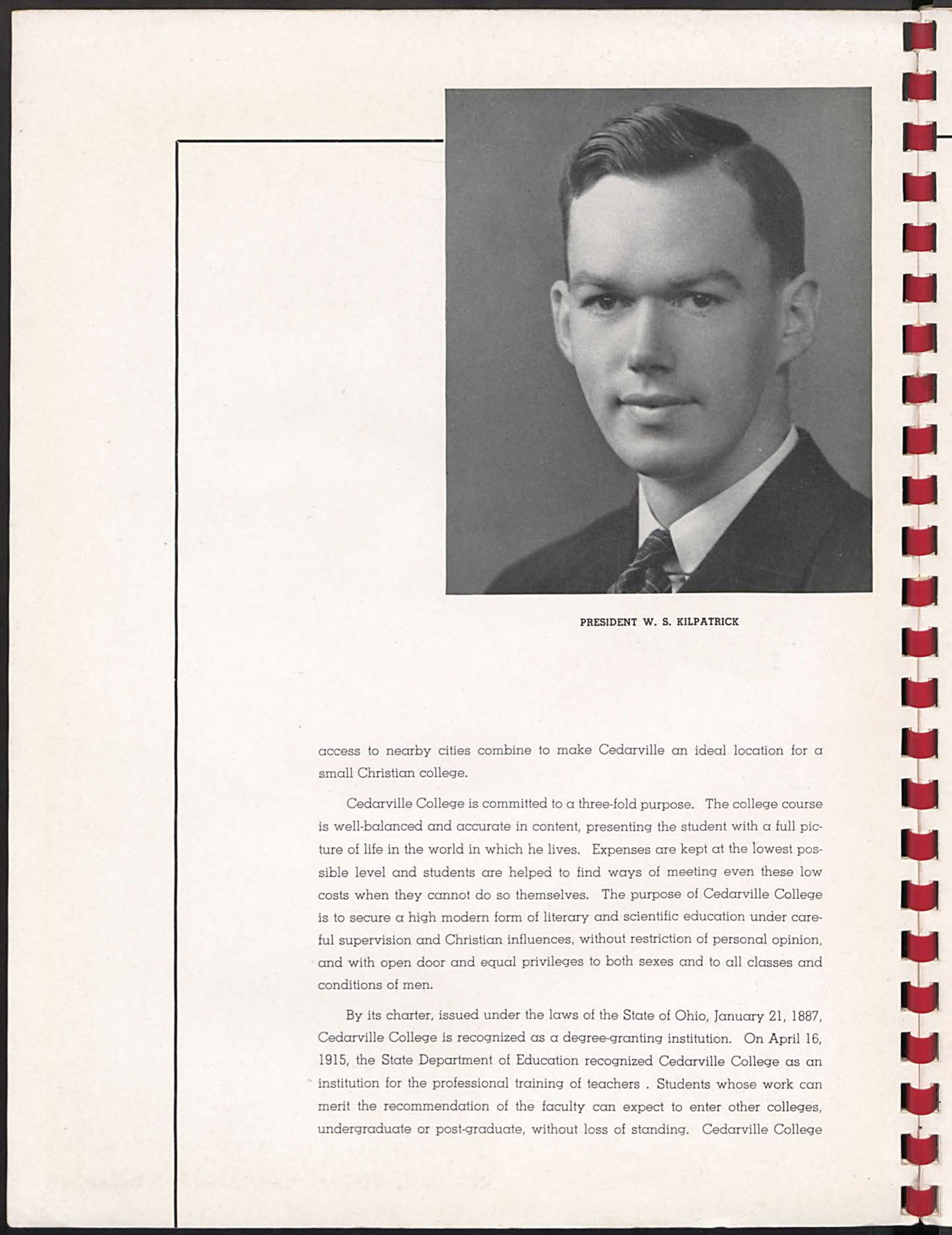




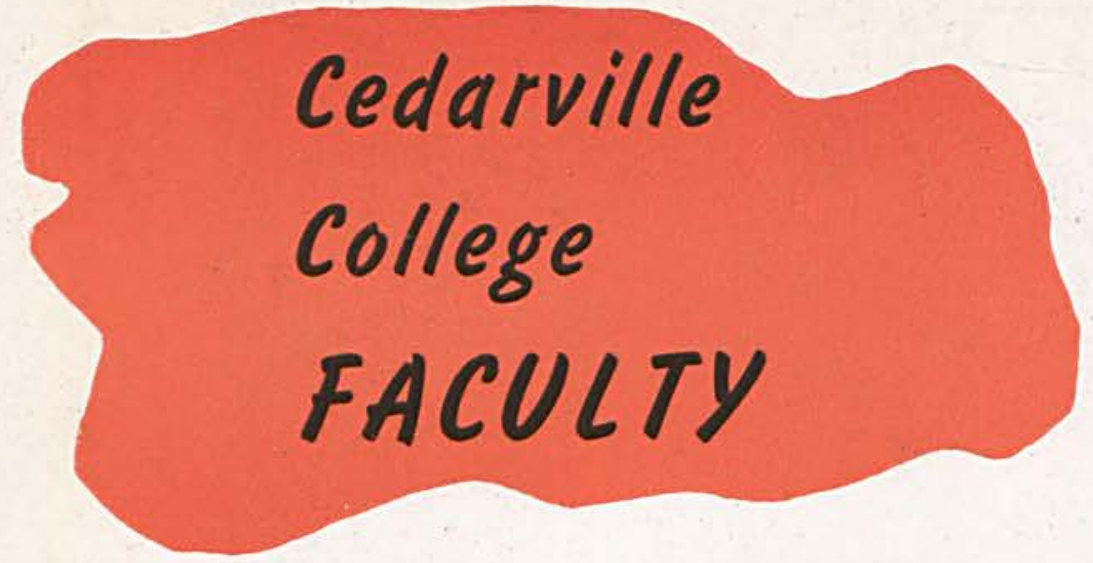

... And now I'd like to introduce the faculty. In the office we find MISS BASORE (she's always busy at the typewriter), and MR. VAYHINGER, our new and well-liked business-manager. PRESIDENT KILPATRICK ("Pat") will be around somewhere.

DR. JURKAT'S hangout is at the head of the stairs. He keeps his door open invitingly and has a box of crackers ready to feed his classes, as well as to give them a variety of knowledge.

Across the hall is MISS NIESTRATH, our petite French teacher. Her hobbies are speeches and Mexico.

If we go up a few steps we find DR. McCHESNEY (Dr. Mac to his classes) with the board covered with Greek letters, teaching under the motto, "Think."

DEAN STEELE occupies the room with all the maps. Anyone in his classes can tell you how much he makes history live by his dramatizations.

The little room in the corner is MISS SANTMYER'S. She really can draw the authors from their covers and bring them to life for us.

If we go to the science building we'll find MR. WOODARD ("Little John") deeply engrossed in some form of science.

Upstairs, MR. HOSTETLER has just returned from the high school where he's been encouraging one of his practice-teachers. He keeps his classes cheerful with appropriate tales.

MRS. KLING performs similar services for the elementary practice-teachers. Her smile is something we all remember.

The room with the pictures all around is MISS HYSELL'S Art Salon, but you'll probably find her over at the gym joining the girls in basketball or ping pong.

COACH PYATTE is somewhere around here too, ready to join one or more of his boys in any game.

MR. HAUPT, the music director, is new this year, but he's working hard to build up the music department.

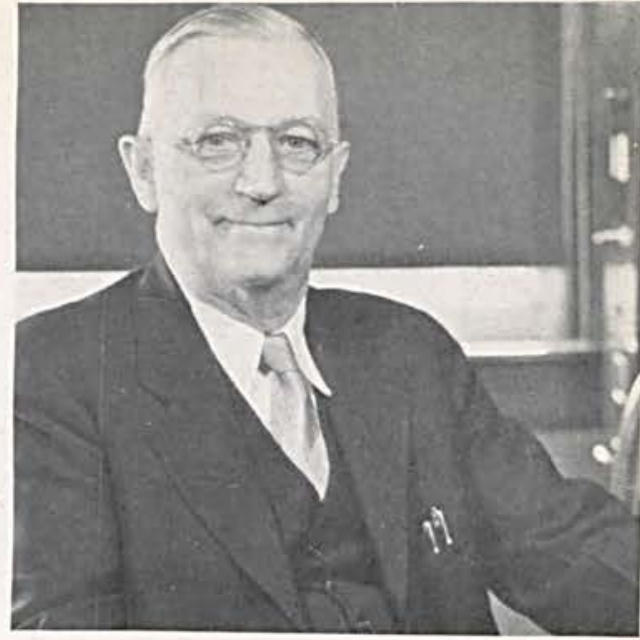

DEAN STEELE

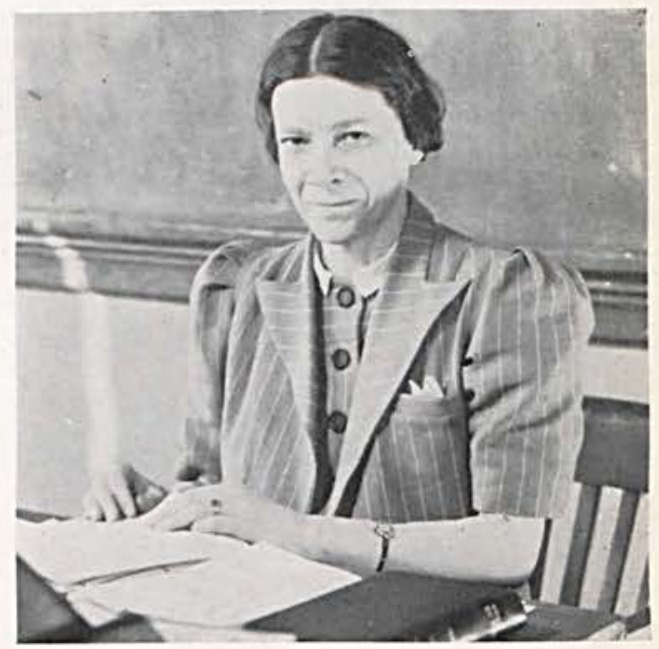

MISS SANTMYER

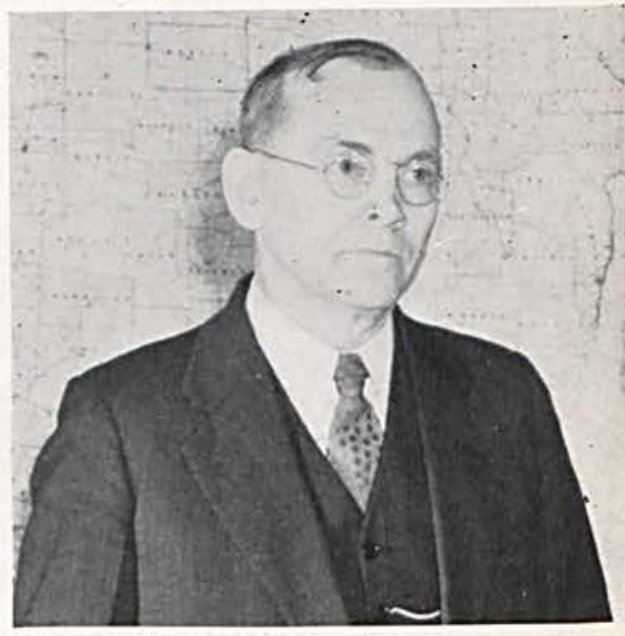

MR. HOSTETLER

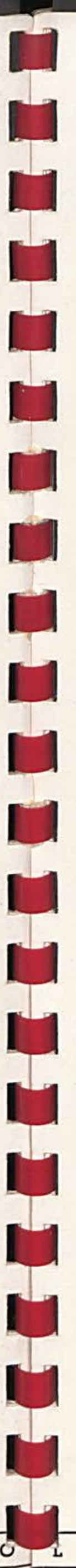




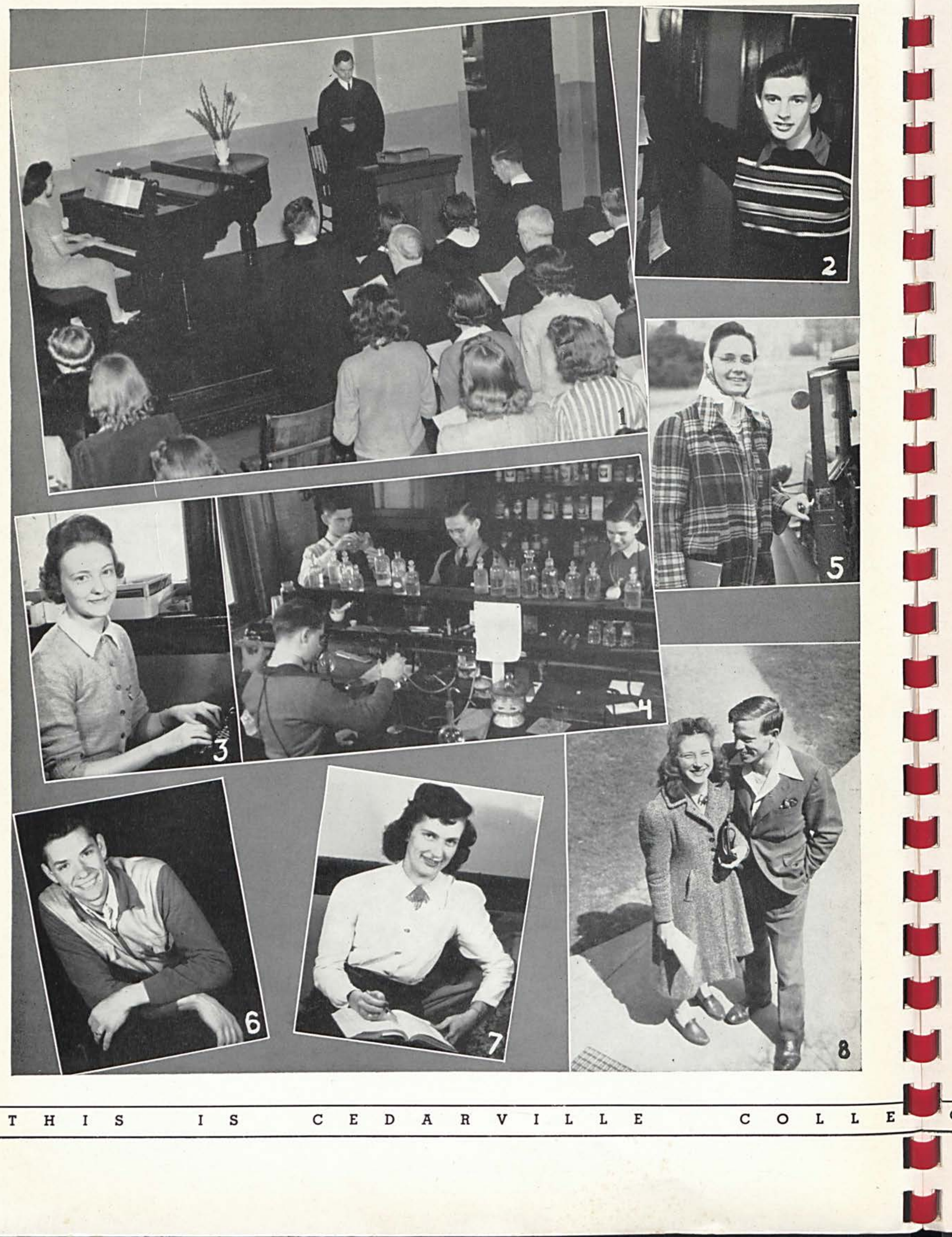




\section{The Stary of the Student Cauncil}

This year, as in years past, the Student Body organized the Student Council. Originally, this organization served as staff and publishers of Cedarville College's weekly paper, The Whispering Cedars, along with acting as the student governing body. Through the ensuing years, however, it has become entirely devoted to its work of solving the civic problems of the students, leaving the Whispering Cedars Staff to publish the school paper.

In various years since its creation in 1933 the President of the college and the deans of the men and women have represented the faculty as members of the "Student" Council, but since 1938 they have not been present to act as active members in the regular Council meetings. Most meetings took place without the presence of faculty members. The faculty has been considered, of course, and has been well represented in all meetings where discussion of problems directly concerning them, or their relations with the students have taken place.

Being started and continued with the thought in mind that cooperation is necessary for the good of all, Cedarville College's 1942 student council has acted accordingly. Priding itself in its democratic ways, the council has given careful consideration to several problems of student relationship in the past year.

In its first meeting it decided upon the shortening of the second semester. This was acted upon by a faculty recommendation and in the presence of faculty represented advisors. The proposed recommendation was accepted, a plan drawn up by which the shortening could be accomplished, a revision in daily and Commencement Week schedules made, and the whole presented to the entire student body for their acceptance.

Another meeting of the Council and advisors was called to consider and accept another change in schedule to conform with the advance in time proposed by the federal government.

Similar meetings were held when a decision was made to revise the old rule book and bring it up to date. This revision is at present still in progress.

The establishment of an honor roll was made by the council this year by which the names of those students having a $B$ average or better are to be published each semester.

The Student Council this year was ably conducted by Robert Guthrie, Student Body President and well represented for the Seniors by Bea Collier and E. Clayton Wiseman, for the Juniors by Bea Williams and Lee Miller, for the Sophomores by Betty Ervin and R. Henry Campbell, and for the Freshmen by Doris Williams and Louis Sweet.

1. The memories of this Easter communion service will live in our hearts forever. No student of Cedarville College will forget the inspiring speeches given in our chapel by people from all parts of the world. 2. An athlete and a scholar who comes from across the street is freshman Keith Wright. Although just a "little fellow," he was active in both basketball and baseball. He also handled sports writeups for the newspapers. 3. Dorothy Bogenrife who comes from Mt. Sterling, Ohio, is an elementary teacher who graduates this year. "Dot" stays with Miss Basore and has been Prof. Steele's right hand man for three years in N.Y.A. work. 4. Chemistry has become an important part of everyday life within this last year. Cedarville is doing its part in the great "speed up" program to start young men on their way in the field of chemistry. 5. A product of a neighboring village of Jamestown is Miss Mary Eloise Klatt. She's standing at the door of her "Red Dragon," which is fast becoming a campus tradition. 6. John Sanders hails from London, Ohio, and is the mainstay of the baseball team's pitching staff. Johnny, a sophomore, also played basketball and is a charter member of the frat. 7. Beatrice Williams who hails from near London, Ohio, also graduates as an elementary teacher this year. "Bea" is musically inclined, can both play the piano and sing, and belongs to the X $\Sigma \Phi$ Sorority. 8 . Where one is seen, the other shall also be seen. Hank and Laurel are one of the most popular couples on the campus. We would like to say more here, but just look at the third finger on Laurel's left hand and you will know the rest of the story.

G E

$\begin{array}{llllllllll}\text { I } & \mathrm{N} & \mathrm{N} & \mathrm{I} & \mathrm{N} & \mathrm{E} & \mathrm{T} & \mathrm{E} & \mathrm{E} & \mathrm{N}\end{array}$

N

$\begin{array}{lllll}\text { F } & \text { O } & \text { R } & \text { T } & \text { Y }\end{array}$

T W O 


\section{The Stary of the Expansian Program}

The present conflict has emphasized the need for trained leaders in every field. Its use of leadership drawn from practically every walk of life has further intensified the need even in those fields far removed from actual combat. Moreover, it is generally agreed that the social, political, agricultural and industrial problems of the post-war era will demand a very much larger number of qualified leaders.

Cedarville College has had a great history in the training of leaders. The record of her alumni and students has been an unusual one. Furthermore, Cedarville has always made her training available at a very low cost. But she has long believed that many more worthy boys and girls were kept from this training largely by finances. Indeed, authorities tell us that one-third of the most promising graduates of our high schools do not enroll in either colleges or universities. The reason is largely one of finances.

After careful study of this problem, the Board of Trustees has voted to acquire a farm as the first step toward a student self-help program. This farm together with related student industries will provide many new working opportunities and materially reduce student costs.

The reasons for the acquisition of a farm as the basic part of an enlarged student selfhelp program are:

1. We are situated in an unusual farming area.
Greene County with its very large deposit of limestone is one of nature's gardens designed for producing abundant harvests.

2. The students will consume many of the products of the farm. The surplus products will have a ready sale in the open market, thereby solving the sales problem of our work program.

3. Although native ability is confined to no section of our country, yet it is generally conceded that boys and girls from rural areas have exceptional qualifications for leaders, especially where there must be a relationship between what one knows and what he does. Their early contact with the soil and the creative forces of life has given them unusual success in fields where leadership is demanded. The basic farm-work program will tend to develop those deeprooted character and personclity traits so much in demand.

Careful studies carried on during the past several years have convinced us that the sum of $\$ 100,000$ will be needed during the next three years to develop the student-operated farm, to initiate on a small scale other industries that would grow out of it, and to make those capital improvements necessary to carry the experiment beyond its formative stages into "production" on a self-maintaining basis. Of this amount approximately one-half would $b \epsilon$ devoted directly to the building up of the farm and other basic student-employing industries. The remainder would be used for labor grants and loans to needy students, college improvements and equipment, including student housing, necessary salary increases and budget requirements until the self-help project is fully developed. 


\section{The Stary of Sparts}

Sports at Cedarville College in 1941-42 were directed by new instructors. C. D. Pyatte was the athletic coach and Miss Margaret Hysell was physical education director for the girls.

Coach Pyatte issued the call for the baseball squad soon after school started. Because of the decrease in the enrollment, barely enough boys reported to compose a team, but, after $a$ few weeks of practice, the squad had rounded into shape and gave signs of developing into a fairly good ball club.

The team had a pair of practice games scheduled with Wilmington College in the fall, but was able to play only one of them. That game played at Wilmington was decisively in favor of the Quakers; still there were possibilities for a winning Yellow Jacket team, it was thought. Coach Pyatte was of the opinion that, for some reason, the squad did not play the type of baseball of which they were fully capable in that opening game and he looked forward to a better result in the next meeting of the club. However, rainy weather followed by coldness cancelled the game and sent the boys inside for their athletics.

During the fall the girls were participating in soft bail and other out door activities under the direction of Miss Hysell.

When the adverse weather began, Coach Pyatte lost little time in starting the basketball practices. About fifteen boys were on hand for the initial practices. This squad had nearly a month of practice before the season opened. During this time, Coach Pyatte experimented with various combinations. He had only four lettermen to work with and it was evident that he would have to use some of his freshmen or other untried talent in important roles. R. Henry "Hank" Campbell and Harry Stoneburner, both sophomores who starred on the preceding Cedar team and were named to the second I.O.C. all conference team last year, were counted on as main-stays. Other letter-men, John Reinhard, a senior, and John Sanders, sophomore were also slated for heavy duty. Pyatte then began classifying his other play. ers according to ability and experience. $\mathrm{He}$ watched Layden "Buck" Wilson, Harold Corry, Paul Stoneburner, Fred Lewis, Millard French, Laurell Flory, Dave Galey, and Keith Wright in action. None of these players had had any previous extensive experience on a college varsity, but out of these, were to be chosen two, or possibly three starters.

By the time the team was ready to open the season at Tiffin University, the coach had chosen the following lineup to represent the orange and blue in that opening I.O.C. game: forwards, Harry Stoneburner and Harold Corry; center, John Sanders; and guards, Hank Campbell and Buck Wilson. That team battled to a 35-31 loss with only two subs getting into the game, John Reinhard and Keith Wright. Freshman Corry led the losing battle with 10 points.

The next engagement was at Wilmington. The rivalry between the two teams having been sharpened by a "home and home" painting visit, both squads scrapped through a nip and tuck second half to a 33-27 result. Wilmington's first half superiority told the tale as the last period was almost even. Stoneburner racked up 17 points after going in as a sub, and he was ably supported by a hard fighting Cedar team.

Otterbein's overwhelming victory proved $\alpha$ terrific let-down to the whole team. A hot band of Otters, opening their season on their home floor, swamped the Cedars 59 to 35 .

Although Cedarville was never in the game at Earlham, they showed heretofore hidden scoring power. A loose defense cost them another game however, 66 to 44 .

The next game proved no better. Ball playing out of their class and without the services of Corry who withdrew from school, Cedarville lost 74-35 to Dayton University. A vast supply of reserve talent for Dayton seemed to demoralize our boys, but both Campbell and Stoneburner turned in good scoring games.

Getting back to their own league the Yellow Jackets were nosed out in a heart-breaker. The defeat by Indiana Tech $42-41$ was hard to take,

I

I

L




\section{Sparts continued}

for Cedarville led 22-16 at the half and appeared to have their first victory of the season. Another bitter pill was the fact that it was another I.O.C. game. Sanders added the scoring punch which almost netted the win.

Coach Pyatte placed the next game in the hands of his rookies; Flory, Lewis, Galey, Wright, and Paul Stoneburner were given their starting chances against Giffin. They responded nobly and, helped by the regulars later on, they chalked up the first win for the hardwood campaign, 55-33.

The regulars came back with a vengeance against a powerful Wilberforce University team. Displaying better than usual team play, our boys made it tough for W. U. in the first half, leading 19-17 but went down fighting in the second half 37 to 31 .

The game which Cedar cagers would rather disregard is the one at Morehead, Kentucky, State Teachers College. It was a combination of an off night for the Jackets and a definitely on night for the Ky. lads. The result was (sh) 90-37.

Cedarville received a severe set back at Van Wert where they played Giffin U. again. Coach Pyatte's rookies given another chance were apparently lost, and before they were yanked and the regulars inserted the margin of victory had been made. The final score was 51-44. Harry Stoneburner made thirteen consecutive free throws after missing his first three. $\mathrm{He}$ ended the game with a total of 19 points, while Campbell was next with 16.

One of the best performances of the year was on the Indiana Tech floor at Fort Wayne. The regular starting five played the entire game and emerged with a well deserved 3625 decision. Smooth team play was the formula which meant victory.

The home coming crowd suffered with the team in an overtime defeat at the hands of Bluffton, but not before many breathless minutes of good basketball were played. Campbell was high point man with 21 points and $\mathrm{P}$. Stoneburner connected for 14 points on long shots.

Cedarville, with P. Stoneburner hitting again and H. Stoneburner making an all season high of 24 points, ran roughshod over Tiffin 62-42.

The campaign closed with another thrilling close loss to Wilberforce U. This time it was the Force that built up a first half lead only to have Cedarville threaten it strongly in the final period. A 39 to 34 score was the result of the second meeting of the two teams.

Cedarville ended the season with three wins and 11 losses, not an enviable record, but the cagers have offered no alibis or complaints, and neither will we. Surprisingly enough we find that Cedarville, despite some landslide scores were only out scored 686 to 553 , an average of 49 points for the opponents against 39.5 for the Jackets per game. Harry Stoneburner led in individual scoring honors with 201 points; Campbell was next with 137.

Cedarville finished second in the I.O.C. conference, behind the co-champions Indiana Tech and Tiffin U. Campbell and Stoneburner were named on the all Conference team for the second time.

For the first time in the history of the college, the freshmen were crowned champions of the intramural basketball program. A series of six games were played among the class teams. The freshmen annexed the title by defeating the sophomores in the final round of play.

Meanwhile, Miss Hysell's girls' team had their annual home and home series with the Wilmington lassies. In January, our girls were guests at the Clinton County school. The fightin' Quakerettes dined the Cedarville girls after pasting a lop-sided defeat on them on the basketball floor earlier in the afternoon. The C. C. co-eds returned the compliment to the Wilmington girls in March, but were lambasted by another one-sided score.

In intramural ping pong tournaments, Martha Shaw and Laurrell Flory won the honors in the girls division and in the boys' division, respectively. The tourney was open to all students and faculty members.

The baseball squad has been greatly handicapped this spring by bad weather and the shortened college year. They will, however, meet several of the surrounding schools in spring games.

Track and tennis were postponed because of the shortened college year. 


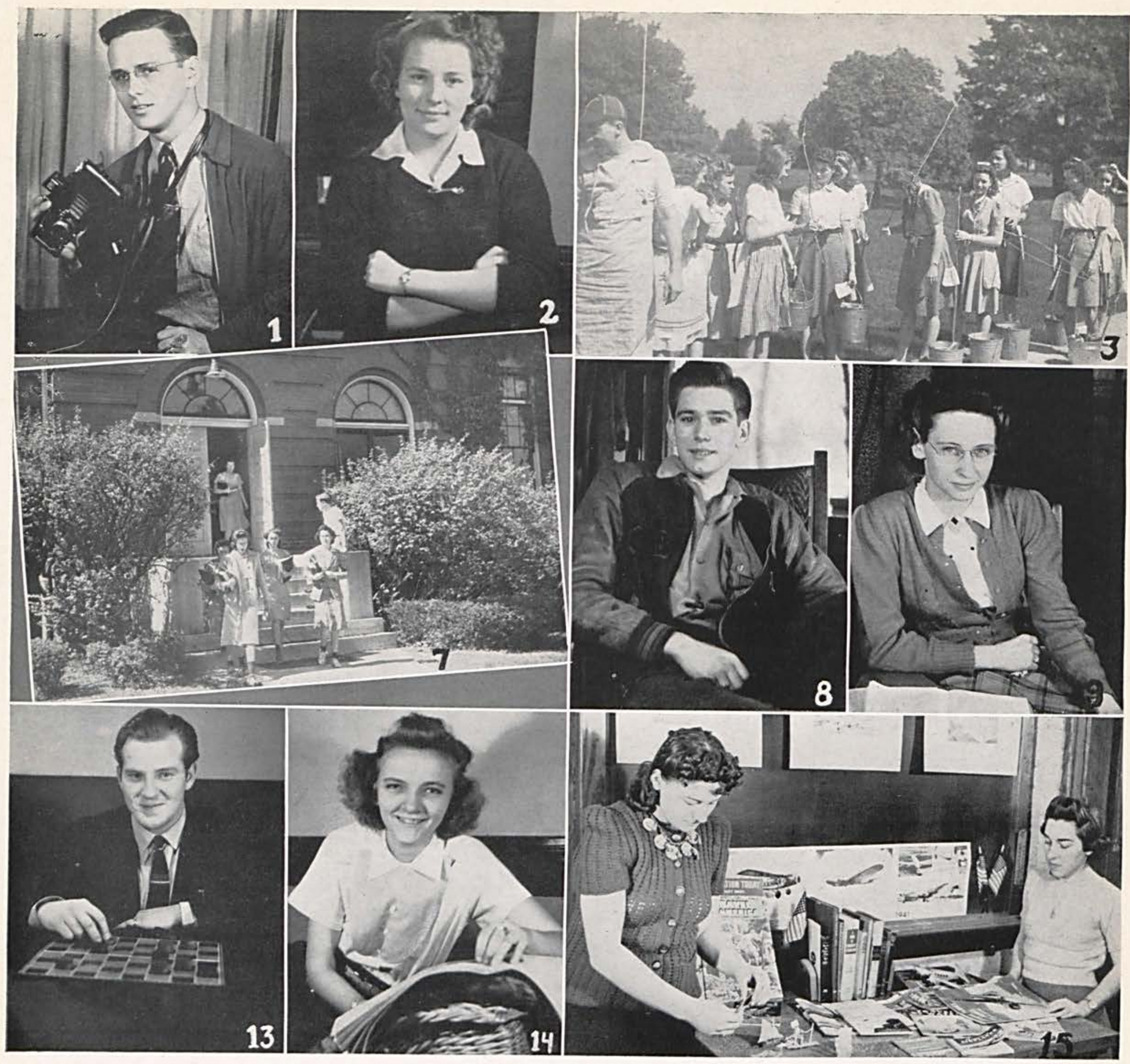

1. Harold Guthrie comes from Apollo, Pa. A sophomore this year, "Hal" turned his affections toward the high school, but re mained very popular on the college campus. 2. Freshman Dormite from Vandalia. Ohio, is Lova Macy. "Lovely" as she has been called by most of the students, is very fond of hillbilly music. 3. Freshies from Cedarville fish for fresh fish. The freshmen are ready for their trip downtown to try their luck on a street corner. It's an old tradition that the freshmen start their life at Cedarville with $\alpha$ fishing trip. 4. President "Pat" gives $\alpha$ hearty welcome to the grads at the Homecoming banquet. Beside him sits the toastmaster of the evening. Dr. Dwight R. Guthrie of Springfield. 5. Beatrice O'Bryant is $\alpha$ product of Ross Twp. and is another of our elementary teachers who leaves us this year. "Bea" is always willing to take part in anything and is a good mixer. 6. Millard French from South Solon, Ohio, is another member of the baseball squad. Although "French" is $\alpha$ little wild, he usually does $\alpha$ good job of pitching. 7. Morning classes are just out. About half of the students eat at the college boarding club. That is where they are going now. They'll be back at 1:00 to go back to work. 8. Harry Stoneburner is the pride of Spring Valley, Ohio. Although troubled by asthma, "Stoney" was the leading scorer of this year's basketball squad and was chosen as a mem. ber of the All-Conference Team. 9. The newcomer to our ranks s Jeanne Mercer from Mechanicsburg, Ohio. She is a sophomore,

$\begin{array}{llllllllllll}\text { I } & \text { S } & \text { C } & \text { E } & \text { D } & \text { A } & \text { R } & \text { V } & \text { I } & \text { L } & \text { L } & \text { E }\end{array}$




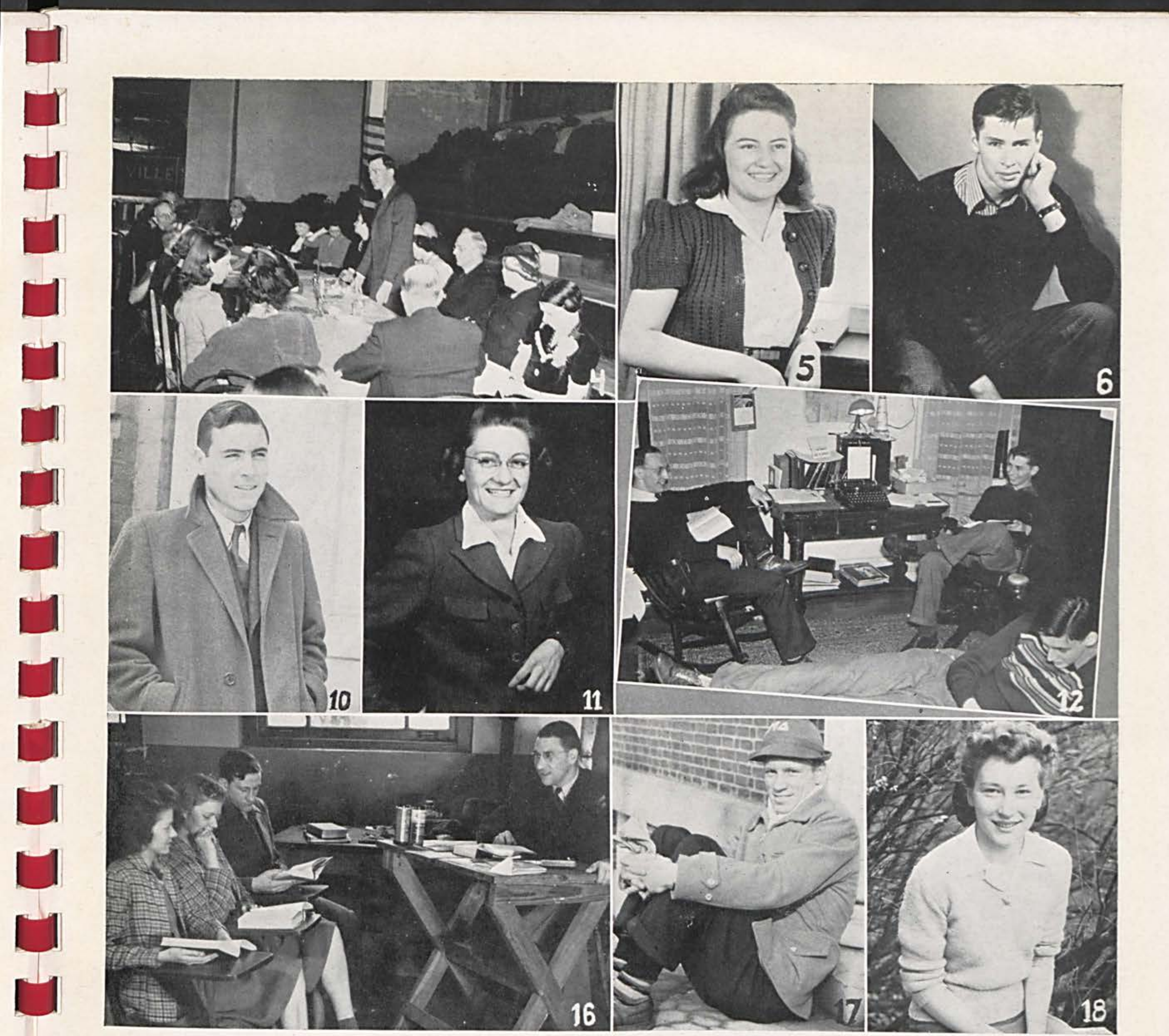

having spent her freshman year at God's Bible School at Cincinnati. 10. Another transfer student is Bill Preston, sophomore, who comes to us from Ohio State. "What's cookin', Bill?" 11. Helen O'Bryant from Jamestown, Ohio, is one of our eelmentary teachers who graduates this year. She has been active in sorority work serving as president of the AӨT this year. 12. Just a quiet evening of study together. Often the fellows gather in their rooms, study together, then relax and have $\alpha$ little fun. This is college life. 13. William E. Meahl is another fellow from Xenia, Ohio. A sophomore this year, "Bill" is $\alpha$ charter member of the XM $\Delta$ fraternity and thinks in scientific terms. 14. Jean McClure, "Bill's girl" is a freshman from Urbana, Ohio. She's $\alpha$ member of the chorus and pledge of the XMI Sorority. 15. Bea O'Bryant and Elleanor Young have quite a collection of books and models here. They will use these to teach the children in the primary grades when they take up their teaching career 16. One of the smallest classes is taught by Coach Pyatte. He has just three students in his hygiene class, but they are really interested. 17. R. Henry Campbell, from Enon, is one of the best athletes and scholars on the campus. "Hank" is a sophomore and made the All-Con. ference Basketball team this year. 18. Laurel Diltz comes to us from Springfield, Ohio. "Red" is a sophomore, engaged to "Hank" and possesses dramatic and artistic abilities surpassed by few here. 


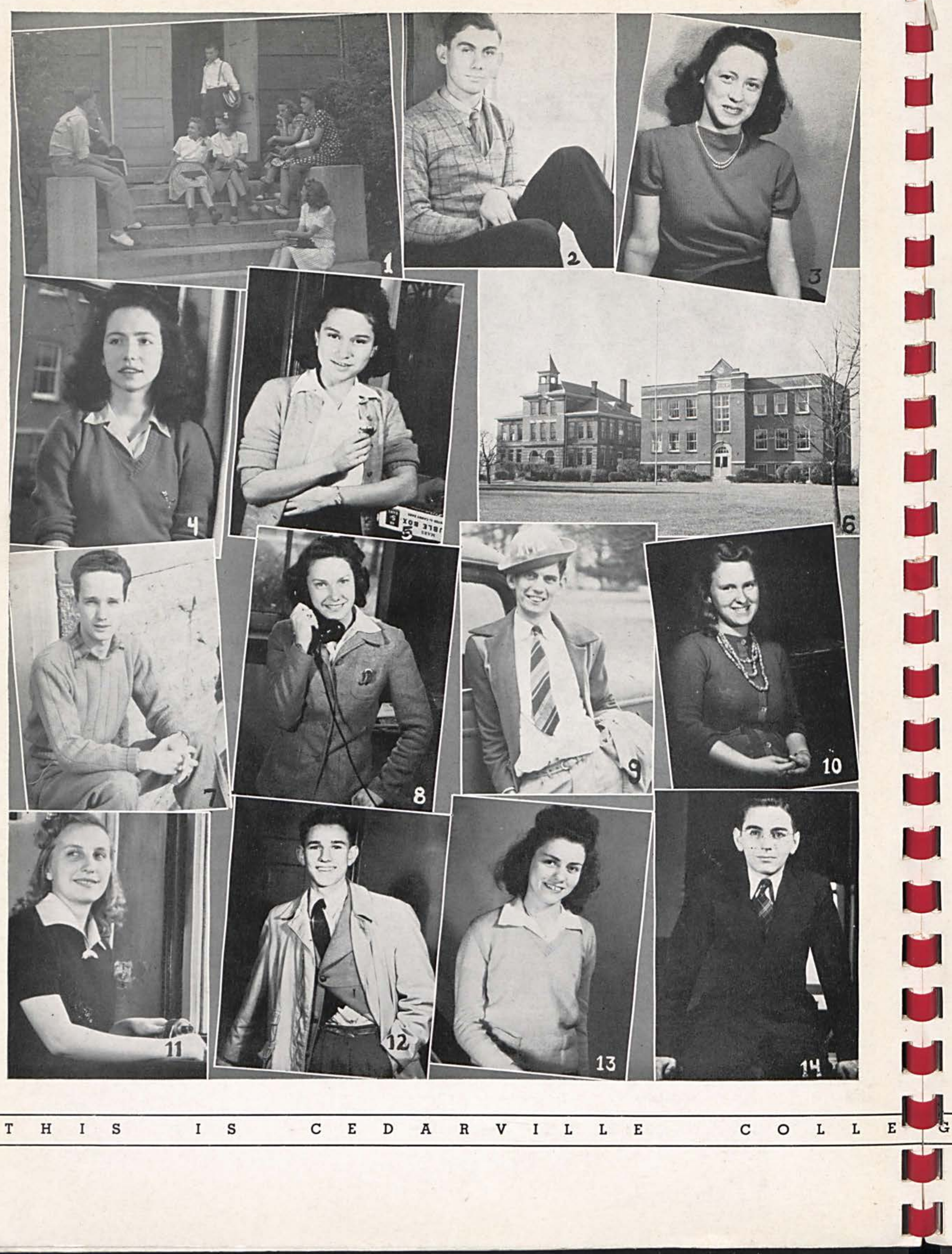




\section{The Stary of Music and Dramatics}

The Dramatic Club of 1941-42, consisting of about twenty members, was organized under the supervision of Miss Basore. The following officers were elected in the second meeting: President, Laurel Diltz; Vice President, Dorothy Bogenrife; Secretary, Beatrice O'Bryant, and Treasurer, Clayton Wiseman.

At one meeting a quiz program was enjoyed by all who participated. Two one-act comedies and one skit were presented this year by members of the club. They revealed dramatic ability in the society and much of their success was due to the director, Miss Basore.

A one-act comedy, "Who Gets the Car Tonight?" was presented at the College and upon request was given later at the High School at Carlisle, Ohio. Members of the cast were: Clayton Wiseman, Helen O'Bryant, Dean Babb, Wanda Hughes, and Robert Allen.

The next presentation was a skit, "Meet the Duke." The parts were played by Alton Earnhart, Maxine Heinz, Dorothy Clark, and Betty Irvine.

"Mushroom's Comin' Up" was a high-light of the year. Its success was proven by the request to be performed three times, two times at the College and once at Geyer's Restaurant in Xenia for the Cedarville College Alumni Association. The cast included, Mary Alice O'Bryant, Laurel Diltz, Beatrice O'Bryant, Velma Henderson, Dorothy Bogenrife, and Beatrice Collier.

The year was ended by the class play "The
Family Upstairs" with the all-star cast: Laurel Diltz, John Reinhard, Orsadee Stewart, Clayton Wiseman, Rachel Neal, Keith Wright, Beatrice O'Bryant, and Beatrice Collier.

The choir this year was under the able leadership of Oscar Haupt. Several very good performances were given, including a broadcast at Columbus under the auspices of the Alumni Association of Cedarville College. This performance was highly commended, and all the members enjoyed the trip immensely. The choir also sang at the Men's Bible Reading Contest, at Committal Service, and at Chapel. Another of its outstanding performances was the Christmas Candle-light Service, very well done and much enjoyed by everyone.

The second semester the mixed choir was organized into a girls' choir. This performed several times, including a performance at Baccalaureate.

Credit must be given to the sextette which sang at the Teachers' Reception and at chapel, and to several individuals, Doris Williams, Orsadee Stewart, and Harold Guthrie for solos and duets. Characteristic of Miss Williams is, that she is always there with a song.

An orchestra was organized under the leadership of Mr. Baas of Cedarville High School. This gave excellent performances at the Teachers' Reception and at the Home-coming.

This was Mr. Haupt's first year at Cedarville, and he can be commended for the excellent work he produced.

Other music enjoyed was the carolling done at Christmas time by all interested members, singing at the dorm at open-house, music at noon in the chapel, and other informal music times.

All in all life at Cedarville has been inspired and cheered by the performances of the musical organizations and of the dramatic club.

1. In spring a young man's fancy turns to - well anyway, in.spring a college student's fancy turns to the outdoors.. The students enjoy their noon campus chats. 2. Donald Brown, from London, Ohio, was a freshman who spent the first semester here. Even though he was only here for a short while, he was well liked by everybody. 3. Dorothy Clark hails from Germantown, Ohio. "Rosie" is a sophomore who is interested in Kentucky and "Bennie" along with preparing to teach in the elementary field. 4. Florence Andrews is a product of Xenia, Ohio, and one of the "Dormites." Flor seems to have found new interests this year as a sophomore, one of the most important being "Bud". 5. Wanda Hughes moved from the high school across the street to the college as a Freshman this year. She lives in Cedarville and is a pledge of the XZ $\mathbf{X}$ Sorority. 6 . And here you see a view of "Old Main" and the Science Hall. In these two buildings, the majority of the classes are held. The flag flies every day on the Cedarville College campus. 7. Robert Allen is from Dayton, Ohio. A sophomore this year, "Bob" has been active as a member of the XMS fraternity and as "Bea's" boy friend. 8. Maxine Heinz, from Bowersville, "Mickey" to every. one on the campus, is the cute little redhead who gets into everytihng at the college. This year as a Freshman she was pledged into the X $\dot{\phi}$ Sorority. 9. Allen Craig hails from South Charleston, Ohio. As a sophomore this year, Allen has served as editor of the "Whispering Cedars" and likes the front porch of the dorm. 10. Another Cedarvillian is Almeda Harper. Although she is gone from our midst and is now working for Uncle Sam, she will be remembered by many. 11. Betty Irvine from Cedarville is also a graduating elementary teacher. She is active in the work of A $\theta$ T Sorority and a good student. 12. Paul Stoneburner is the Freshman Class President, a basketball player, and a baseball pitcher, as well as a good student. Pee Wee Stoneburner is the Freshman Class President, a basketball play er, and a baseball pitcher, as well as a good student. Pee Wee
hails from Spring Valley and is a younger brother of Harry. 13. Alma Davis from London, Ohio, is another member of the sophomore class. Alma's main interests seem to be "Ed" and the ford. 14. Mark Weddle is a sophomore from Springfield, Ohio. who is striving toward an engineering degree. "Ed" may be seen often at Harriman Hall or in his ford.

$\begin{array}{llll} & \mathrm{R} & \mathrm{T} & \mathrm{T}\end{array}$

Y 


\section{The Stary of Religion}

Human beings are an eternal source of mystery and wonderment. Unpredictable, delicate, strong, flexible, endurable, good, bad, humans are divergency itself. Permeated with life and feeling, subject to stimuli of an endless variety, humans respond in crazy fashion to existence. A pickle may cause someone to lose his job. A dirty look may shatter the hopes of a promising day. A kind word may stimulate the timid soul to command a nation. A war may leave a man unchanged, steady, and sure. So great is the variety of life's reactions.

Men love life, hold her, and struggle to beautify and enhance her. Some teach, some preach, some farm, some beg, some build, some destroy. In an endless fantastic pattern the threads of life intertwine to make a world throb, and rock, and weaken, and recover.

This particle of matter, insignificant yet vital, in the galaxies of space without beginning or end, has nothing of wonderment, nothing of mystery except its abundance of life, most mysterious of all existence. In creeping things, in plants, in crying things and swiftmoving things, in fighting things and loving things, in man life flows with uninterrupted flow.

Ambitious men, superior men, important men, educated men, purposeless men exist at the same time. Men are different in a great many ways but every man has an attitude, an ideal, a philosophy, a faith, a religion. This religious part of man causes man to struggle, to wonder, to seek, to ask, to think, to pray, to grow. And complete is the man that does all these religious things.

These religious things have a place in the life of every student. Farseeing educators answered the need and we are provided with ample religious opportunities.

Foremost, the lives of our college staff keep us mindful of religious living by word and deed. Actual student participation in religious living is most marked in interstudent relationships. It is not the Y's, the chapel programs, the discussion and forum groups, the church and choir activities that predominate religious life at Cedarville. It is the friendly spirit, the will to learn, the ability to wonder and to think, the privilege to pray and to grow in the classroom, on the campus, at the games and parties that give us experience in actual religious living. These various organizations merely afford analysis, breathing spells, and stepping stones to higher thinking and nobler conduct.

Religious people, although frequently found in so-called religious organizations, are religious only because of their way of living. So when someone asks about the religion of Cedarville students, we can say certainly they are religious. They are continually struggling, wondering, seeking, asking, thinking, praying and growing.

1. One of our juniors who hails from the "Green Mountain" state of Vermont is Lee Miller. Lee has been active in $\mathrm{Y}$ work, is a good student and president of his class. 2. One of Cedarville's most beautiful spots, off of the college campus, is the waterfall at the Cliffs. During the winter the falls freeze and form a shimmering cascade of ice and snow. 3. Betty Ervin is one of our twins from Xenia, Ohio. She is working summer and winter preparing herself for medical school. Although only listed as $\alpha$ sophomores, she leaves us this year. 4-5. These two pix go together. When we see the library, we think of the faithful librarian, who does so much work and gets so little credit for it. Miss Mary Williamson, affectionately called Miss Mary by the students, gives help to one and all. If you need reference material Miss Mary will help you find it. 6 . It's surprising what $\alpha$ bright sunny day can do to one's disposition. Buck and Bill are singing the song of our alma mater, but it would be hard to recognize it if you heard their version. 7. Alton Earnhart, a freshman, from Waynesville, Ohio, is one of the residents of the Lackey house. "Butch" is a quiet lad, who is one of the pledges of the frat. 8. Another freshman girl, who is not in our midst now, is Betty Mosier. Her charming smile won her many friends in her short stay. 


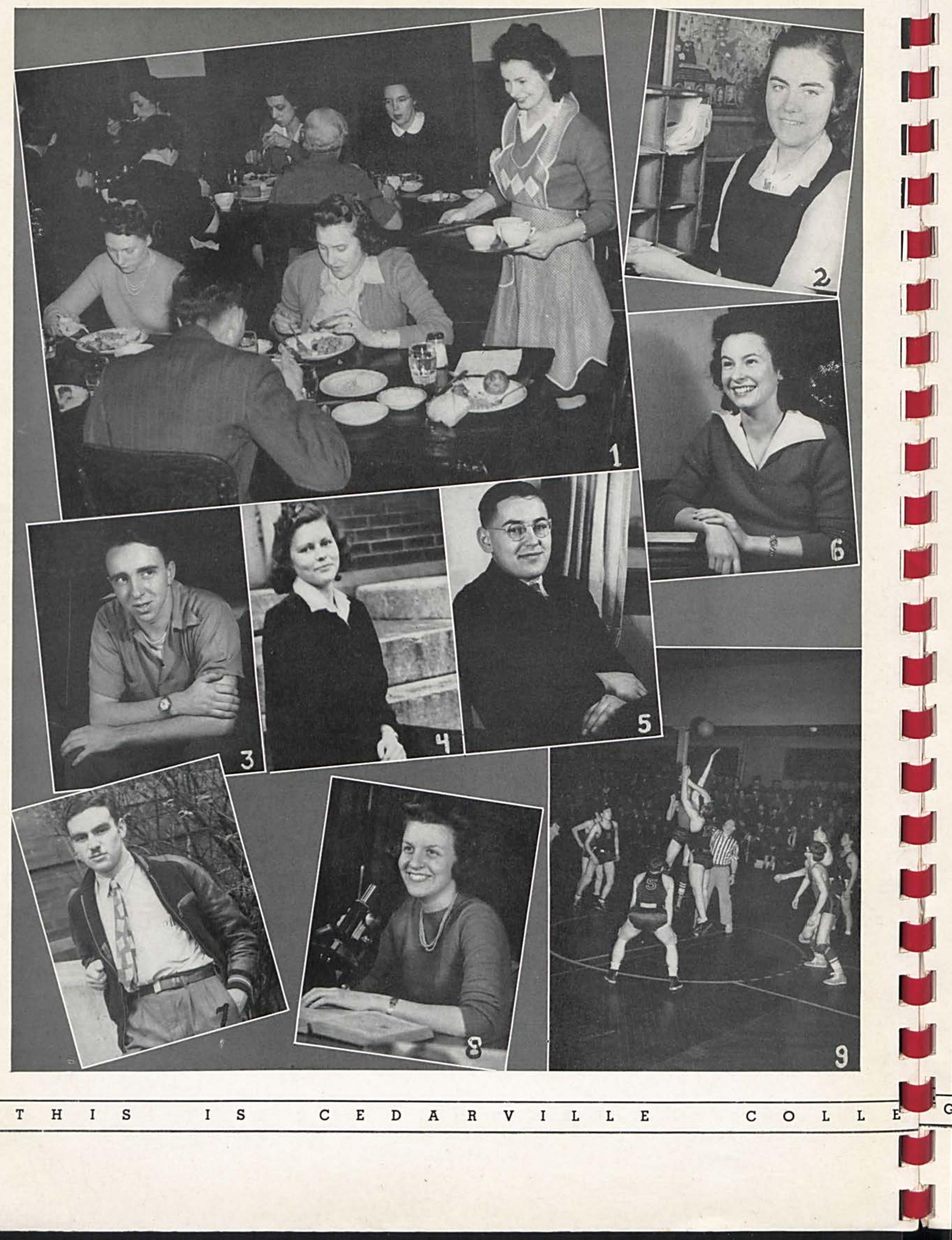




\section{The Stary of Fraternities and Sararities}

In 1683 a young man founded a colony "where brotherly love and toleration should be active forces in men's lives." In 1942 we are still striving to uphold this ideal. If a smile will help a friend to start a successful day, "a smile for everyone" is our duty.

Two sororities and one fraternity have tried to help spread the feeling of "brotherly love" on the campus this year, and as organizations have enjoyed furnishing entertainments for the school.

\section{Chi Sigma Phi}

The girls of the Chi Sigma Phi Sorority have been fortunate to have the enthusiastic cooperation of Miss Niestrath at their regular meetings at Harriman Hall this year.

Parties of the organization varied from Chili Suppers to Theater Parties, and these intimate associations brought love and laughter to the heart of every member.

The Christmas Season was filled with the initiating of lst semester pledges, the making and selling of dainty boxes of candy, and the planning of the Annual Chi Sigma Phi Alumnae Christmas Dinner.

The second semester hailed the fun and frolic to be anticipated from learning to know a new group of interesting pledges, who really "showed their colors" at the "Gingham Swing."

The crowning event of the year was the Spring Formal. The music of Cedric Adams beat out the time, while friends, old and new, danced amid the swinging of balloons and crepe paper and the scent of flowery arches.

\section{Alpha Theta Tau}

In the fall of ' 41 three active members, with the cooperation of Mrs. Kling and Miss Hysell, began the 11 th year in the history of the Alpha Theta Tau Sorority.

It was a pleasure to have Miss Hysell be another one of our faculty advisors.

Every month was held a meeting during which were made plans for the events of the year.

Highlights of the year included a Valentine Dance, Weiner roast at Bryan Farm and a Theatre Party for the "rushes.'

The Sorority welcomed four girls into our "circle"; June Ervin, Eileen Brown, Doris Williams, and Mary E. Klatt.

The History of The Chi Mu Delta Fraternity

The Chi Mu Delta Fraternity was founded in September of 1941. The founders and charter members were: L. Wilson, D. Galey, R. Allen, L. Miller, J. Sanders, R. Guthrie, H. Guthrie, W. Meahl, A. Craig, and H. Campbell. Coach Pyatte was chosen as faculty advisor.

At the first meeting the following officers were elected: L. Wilson, Pres.; L. Miller, vice president; H. Campbell, secretary-treasurer; and J. Sanders, Sergeant at arms. Meetings are held the first and third Mondays of every month. The Constitution was written and arranged by Henry Campbell and Wm. Meahl. Robert Allen wrote the pledge, and it was accepted by the Fraternity. The Fraternity was fully organized on the First of October, 1941. The colors chosen were, white, blue, and gold. The emblem is a shield with the Greek symbols $\mathrm{XM} \Delta$ on it. The letters run from the lower right to the upper left corners. In the upper right corner is a crossed sword and broad axe. In the lower left corner is a torch.

On Feb. 5, 1941, the first pledges were taken in. March 23-28 was held for "Hell Week."

1. The student Co-op Boarding Club serves such good meals that the college professors and high school teachers eat there. The stewards are to be commended for the splendid meals this year, but remember the cooks, Mrs. Morton and Mrs. Gilliam. 2. One of our scientific-minded girls is sophomore Mary Alice O'Bryant. She can be found either at the dorm or at the science lab. 3. Dick Anderson is another contribution of Xenia. Dick plays first base on the baseball team and he hails to the name of Andy. 4 . One of our freshman commuters is Martha Shaw, who drives from near Pitchin everyday. Martha is $\alpha$ very popular and a pledge of the Chi Sigma Phi. 6. Eileen Brown from near Middletown is also an elementary teacher who graduates this year. "Brownie" is always in the thick of things and is well liked by all. 6. Alfred "Bud" Fehlman comes from Xenia, Ohio, and is $\alpha$ junior this year. He has been the manager of the athletic team for the past two years and is next year's $Y$ president. 7. A product of Enon, Ohio, is LeRoy Haynie, a junior, who helps Frank Owens and can always be seen working around the school in his spare time. 8 . The other member of the Ervin twins is called Barbara by her parents, but is known to most students as June. She is $\alpha$ freshman, pledge to the Alpha Theta Tau Sorority. 9. "Get that tip Stoney!!!" Paul Stoneburner out jumps this Bluffton player in the Home-coming game. In spite of Coach Pyatte's splendid coaching, the Yellow Jackets were nosed out of this game by one point.

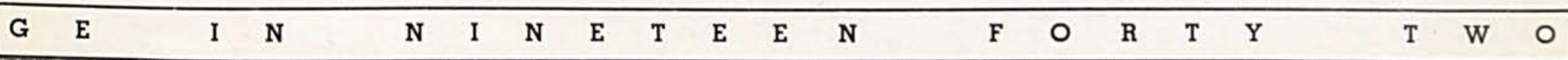


1. Dean Babb hails from Xenia, Ohio. A freshman this year, he is interested in sports and was one of the first pledges of the frat. 2. Doris Williams, and Jean Ferguson come from Springfield and Xenia, respectively.. They are musically inclined, Doris being the outstanding vocalist of the choir and Jean, the accompanist. Doris was pledged to the A $\Theta T$ Sorority, and Jean to the X $\Sigma \Phi$ Sorority. 3. Elleanor Young, a tiny teacher of tiny tots, also graduates in the elementary field this year. Her home is near Troy, Ohio, and she is a friend of everyone. 4. Laurrell Flory from Olive Branch, Ohio, is a junior and is the only one of the Flory Clan in school this year. He is active in sports and always ready to help if needed anywhere. 5. Mrs. Kling's class for primary teachers is very informal. These girls are planning to teach children to use their hands to create things. If you haven't already recognized her, the girl with her back toward you is Bea O'Bryant. 6. The Chi Mu Delta fraternity is a newly organized group this year. They are one of the most active of our college groups. Here the fellows are discussing plans with the faculty advisor, C. D. Pyatte for a "Victory Ball. 7. Meet the group who planned and put over the Spring Formal. The Chi Sigma Phi Sorority was capably led by Bea Collier, who, incidentally, is the Queen of Cedar Day this year. 8. On February 7, 1942, the old grads and the present students got together for the annual Home-coming banquet and basketball game. The banquet was cooked and served by the Ladies Adivsory Board. 9. This picture was flashed as XM $\Delta$ members led the "Victory march through the " $\mathrm{V}$ " and under the American Flag. The dancers formed the Greek symbols of the fraternity and then a large " $V$ " on the dance floor and ended the march with a pledge of allegience to the flag. 10. "Hank" Campbell and Laurel Diltz display one of the "V" posters which were scattered through the college build. ings during "V" week. Hank and Laurel also directed the Grand March at the Victory Ball. 11. The Alpha Theta Tau Sorority is not the biggest group on the campus, but it doesn't take size to have a successful group. The A $\Theta T$ has conducted several dances and parties during the past school year. 12. Here is $\alpha$ group of happy, industrious fellows. They volunteered to carry this table from the Library to the College to help Miss Hysell and the camera club to equip their darkroom. 13. Another junior who is from our neighboring state of Pennsylvania is Dave Galey. Dave is preparing for the ministry and will graduate at the end of the summer term. 14. Martha Finney comes to us from Spring. field, Ohio. Martha is a sophomore who likes dances and parties, but does not neglect her studies for her fun. 15. A freshman from Beaver Creek, Ohio, is Fred Lewis. Fred is one of the mainstays of the basketball team and will prove a valuable addilion to the baseball squad. 16. Marion Muller from Ross Township has a talent for writing both prose and poetry. She is a junior and always has a kind word and a smile for everyone. 17. The scene of the freshmen girls scrubbing the steps of "Old Main" with toothbrushes is $\alpha$ familiar one. Each year this is $\alpha$ part of their initiation, and each year somebody manages to put just a little more dirt on the steps before the scrubbing party.
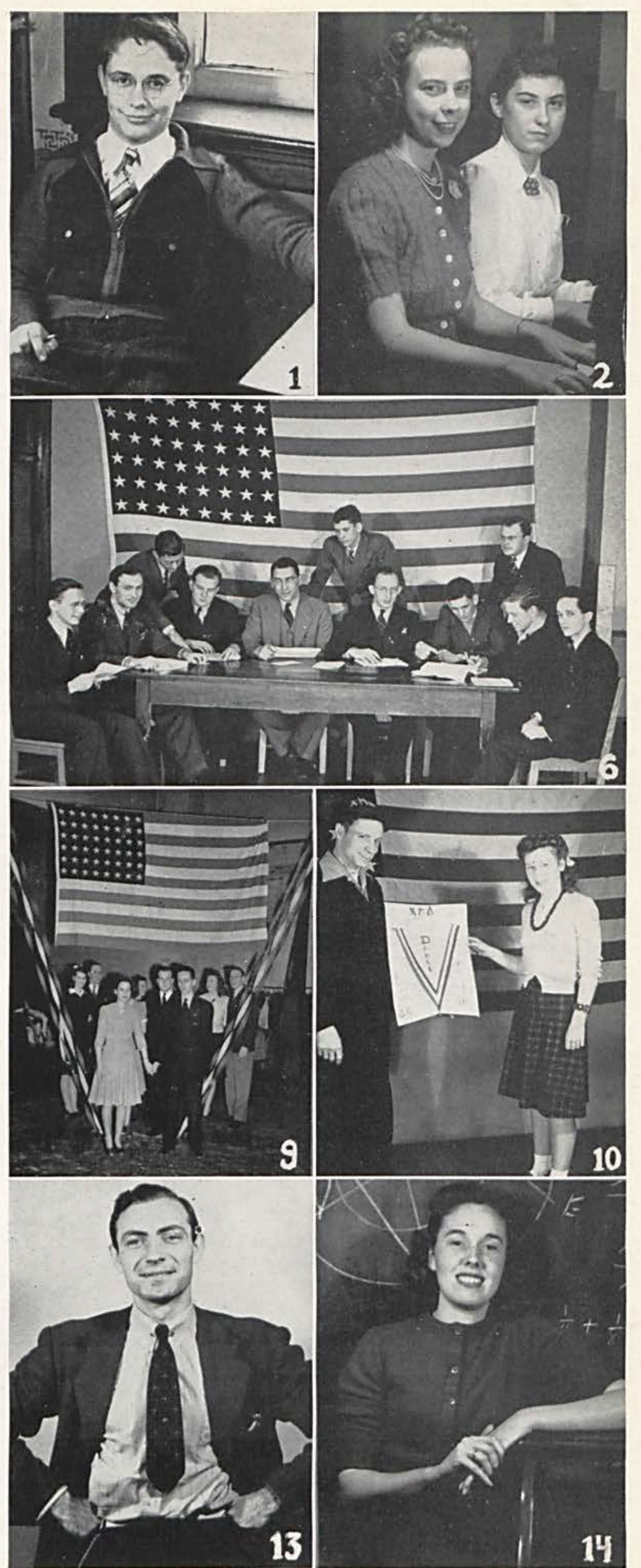

T $\mathrm{H} \quad \mathrm{I} \quad \mathrm{S}$

I $\quad \mathbf{S}$

C $\quad$ E $\quad$ D $A$

R

V $\quad$ I $\quad$ L $\quad$ L

E

C

L

L E 


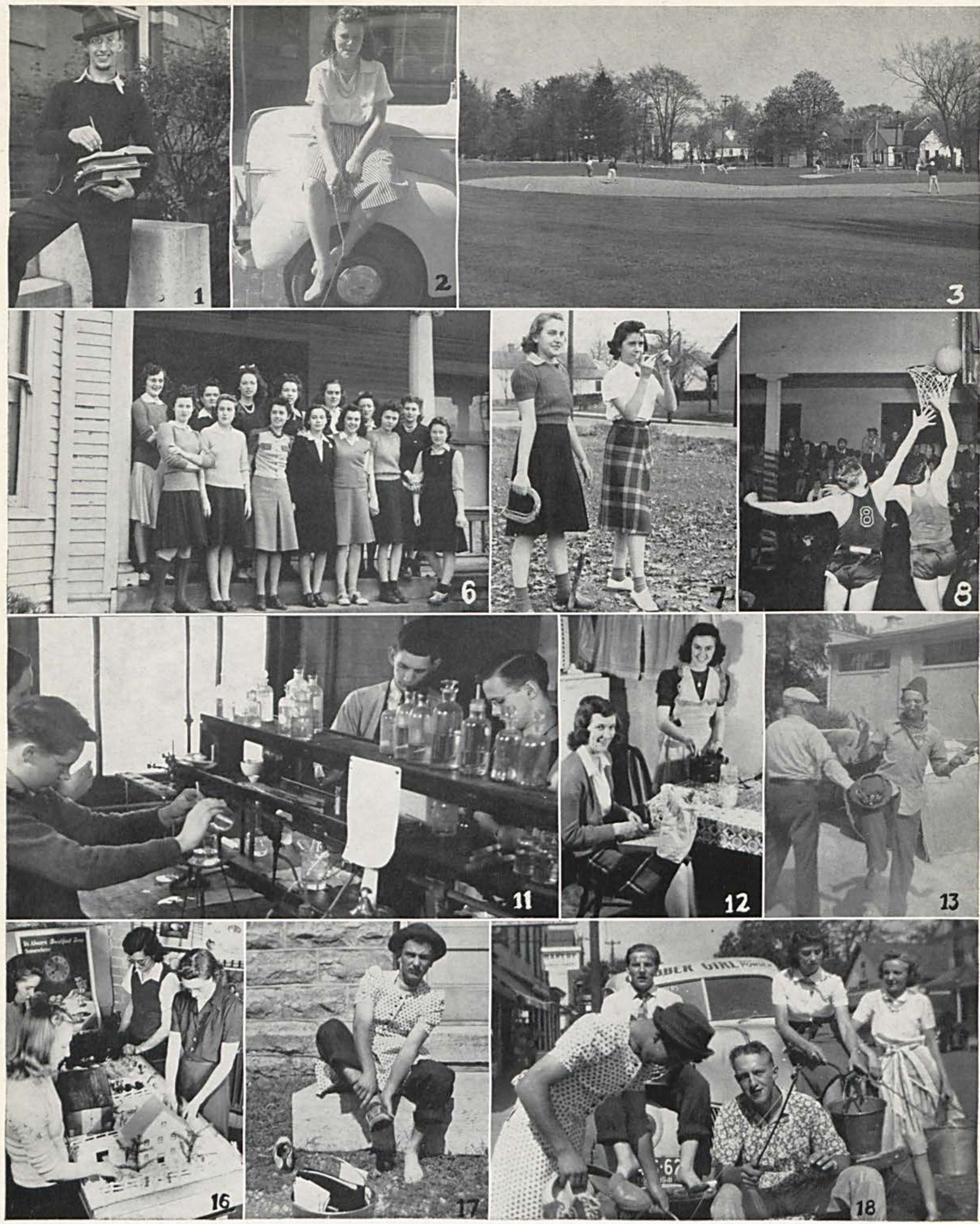

$\begin{array}{llll}\text { T } & \text { H } & \text { I } & \text { S }\end{array}$

$\begin{array}{llllllllll}\text { C } & \text { E } & \text { D } & \text { A } & \text { R } & \text { V } & \text { I } & \text { L } & \text { L } & \text { E }\end{array}$

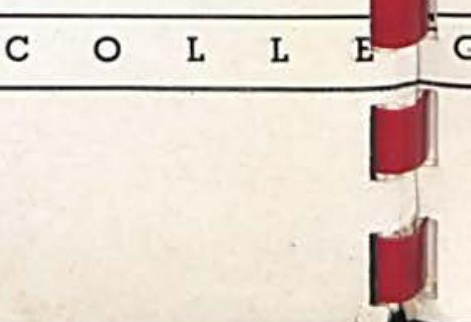




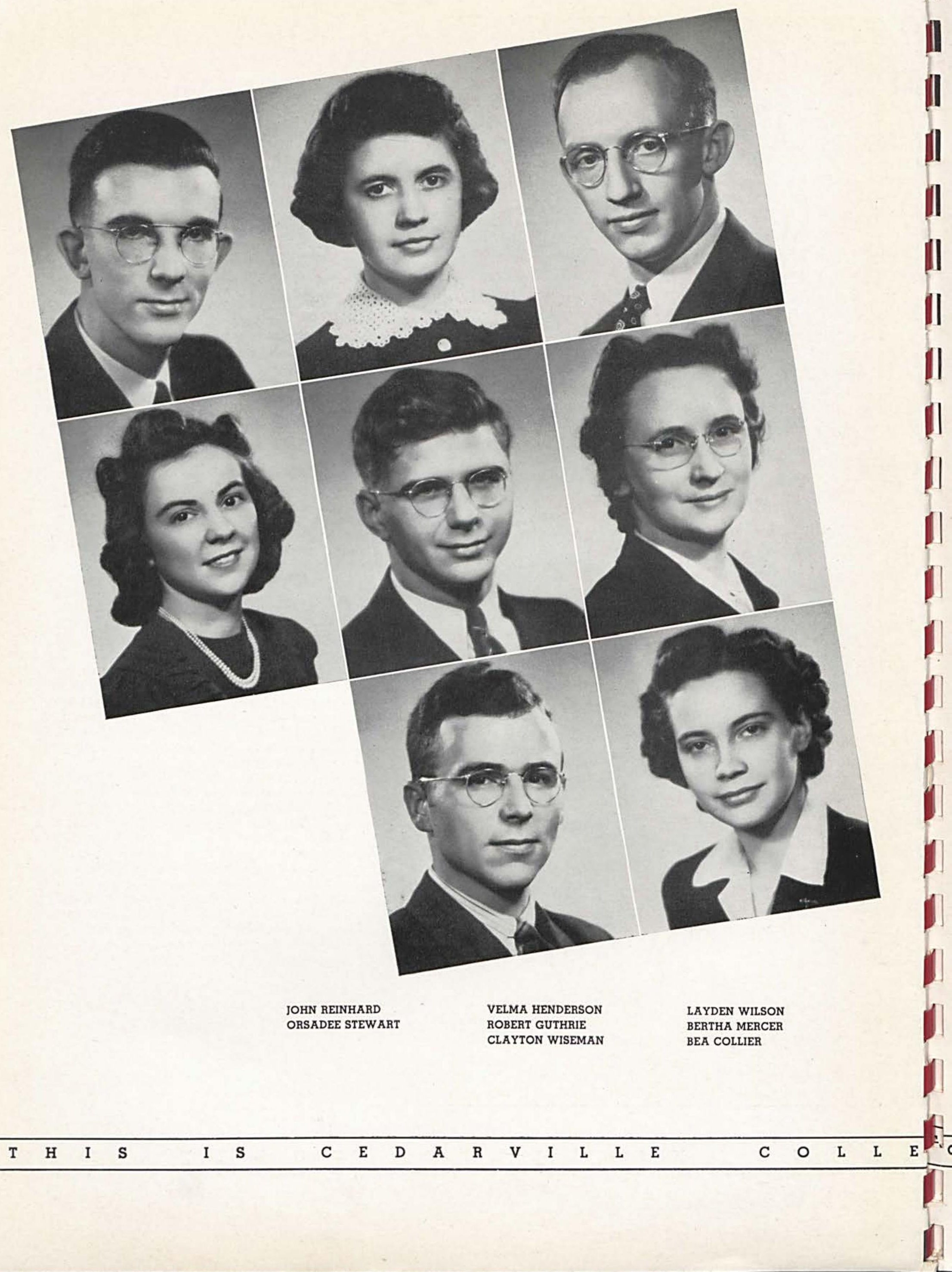


Bertha Mercer, from Mechanicsburg, Ohio, graduated from Fairfield Township High School at Lily Chapel, Ohio. For an interim did office work, then entered God's Bible School and College at Cincinnati. There she was active in religious activities, organized several Bible classes, was president of the Youth's Christian Temperance Union. Graduated from there in 1941 with an A. B. degree, and entered Cedarville College; has continued her religious activities by teaching a Bible class at Cedarville High School and by participating in Y.W.C.A. as a member and as a speaker. She also preaches at various churches. Graduates from Cedarville with a B. S. in Education.

Orsadee Stewart was born and reared in Bowersville, Ohio. After graduating from High School there in 1938, she entered Cedarville College. Dramatic club three years, Y. W. C. A., four years and president, one year; $\mathrm{X} \Sigma \Phi$ three years, president one year; first prize in Bible Reading Contest this year. Among various things she is accomplished in, flower-gardening is the one she likes best. She will graduate from Cedarville with an A. B. degree.

Velma Henderson was born in Selma, Ohio, and graduated from the High School there in 1937. She entered Cedarville College immediately after graduation and stayed for one year. Then she went to the University of Cincinnati for one year. Later she returned to Cedarville for her last two years. In these two years she has been a member of theXI $\Phi$ Sorority, dramatics club, and Y. W. C. A. She served as president of the dormitory for one semester. Her favorite pastime is reading. Will graduate with a B. S. in elementary education.

Beatrice Collier, from Xenia, Ohio. Graduated from High School there as a member of National Honor Society. Entered Antioch for one year, active in glee club there. Did office work for an interim, and returned to Cedarville to finish course. She was a member of Y. W. C. A., of $\mathrm{X \Sigma} \Phi$, of glee club, and of dramatic club. President of dormitory one year, and member of student council. Her favorite hobby is music. Will graduate from Cedarville with
A. B. degree and plans to teach.

Clayton Wiseman was born in Waterloo, Ohio. Graduated from Selma High School with honors in 1937. Was a basketball hero, and after entering Cedarville College continued as a basketball hero. President of class in sophomore year, editor of Whispering Cedars, president of $\Delta \mathrm{K} \mathbf{2}$ fraternity, on Cedrus Staff two years, member of " $\mathrm{C}$ " club, member of dramatic club two years, member of Y. M. C. A. Spent one summer at Lake Geneva in connection with Y. M. His favorite pastimes are sports and reading. Will graduate from Cedarville with an $\mathrm{A}$. B. degree.

Robert Guthrie is one of our Pennsylvania boys. He graduated from Apollo High School in 1938. As president of class for several years, he has brought us through many parties, and other things both large and small. Member of Y. M. C. A. for four years, member of choir for four years, and member of quartet; member of Chi Mu Delta Frat, bus driver, president of student body, and this year has been assistant teacher at Cedarville High School. Will graduate from Cedarville with an A. B. degree.

Layden Wilson also comes from Apollo, Pa. After graduating in 1937 from High School in Apollo, he later came to Cedarville College. Member of dramatic club, varsity basketball team two years, and this year has served as first president of $\mathrm{XM} \Delta$ fraternity. Drives school bus, and for two years has been an efficient steward of the boarding club, member of Y. M. C. A. for four years. Whenever anything happened at College, you could always count on Wilson to be in the middle of it. Will graduate from Cedarville with an A. B. degree.

John Reinhard graduated from Cedarville High School in 1938. Has been a member of Y. M. C. A. for four years, and dramatic club for four years, giving some good portrayal in plays. Has been active on basketball floor and in other sports. Member of XMs frat. This year has undertaken the task of being editor of Cedrus. Has served as laboratory assistant in Science department. Will graduate from Cedarville with A. B. and B. S. degrees. 


\section{The Stary of Life at the Darm}

Dorm life begins at sun up with a brief, brisk scurry of the fifteen girls.

Sheets and blankets are tossed into weird figures. Girls! Girls! scamper across carpeted floors in bare feet. Aluminum curlers click and a tinkle of the housemother's bell calls all to a warm breakfast.

Down at the dining-room table the girls assemble in array of the present and past. The conversation ranges from the quality of the food to the close criticism of the passersby. Everyone reports with exaggerated airs the amusements of the night before.

After breakfast the old question of "What shall I wear" must be decided. The girls survey one another's wardrobe and costume jewelry. After unsuccessful attempts to make a size 32 dress fit a size 34 , a return is made to their wardrobe only to find that someone else had been there before and had borrowed the coat to the needed suit.

At twenty till nine they hurry off to class, trudging down the fire escape with an arm load of books.

At the approach of evening the girls return with more vigor than when they left. They solemnly agree that a little work is good.

From five to six the hour is employed again in dressing. They must be scrumptuously neat for the most important part of the day.

Supper is served at the club at six, after which there are various evening entertainments such as walks, talks, movies, and parlor romancing.

At nine the hardwood door is bolted and a jam session of thirty minutes is permitted.

When the small shiny handbell is rung announcing quiet hours, the girls are supposed to change over to the intellectual side of life (if that's possible).

The girls think that the best book is a closed book; however the never-ending task of lesson preparation must be faced.

There are those that choose the closed-book policy. The housemother travels upstairs to exercise her powers of authority, but to her surprise, finds the "rats" are sleeping as peacefully as "kittens." Perhaps if she would open a closet door she would find them huddled in a corner like mice.

The stuffing of pajamas is a common act. Some innocent girl, free from the evening pranks, slips in at a late hour from a date, so as to make no noise to awaken a sleeping dummy who, she thinks, is her beloved roommate. It must be admitted that these dummies look more sensible than the girls that stuffed them.

At twelve midnight, these girls suddenly realize that their evening of study is almost gone. Assuming a serious attitude, they study forty-five minutes and then drop off to sweet dreams, or night mares. Once in a while a good scare is experienced by one to add a thrill to the life in the dorm. For instance, the episode of the man in a tan suit just ready to enter the house when he was discovered.

Being all for one and one for all, we comfort the poor frightened creature and shyly inquire, "What did he look like?" My goodness! What a romantic bunch.

1. Last Cedar Day (1941), as many of you will remember, Wilson and "Lucky" Logan had a steamroller. After the program, Dean Steele consented to pose for this picture. In his classes he often asks the question, "What is a juggernaut?" Here, Professor Steele, is a juggernaut! Cedar Day has become a tradition at Cedarville College. Each year the students have a program of music, comedy and dance. This program is held either in the Alfred Gymnasium (2) or out on the college campus. The 1941 queen was Elisabeth Anderson (5), affectionately called "Puddy" by her friends. Along with her duties as Cedar Day queen, 'Puddy" had charge of teaching the Maypole Dance and other dances. A fine comedy team was discovered last year in "Buck" Wilson and "Lucky" Logan. They were assisted by Elwood Shaw. In picture number three we see the girls entering the boarding club in the library building. The club serves excellent food to about forty students each meal. In number four we see Allen, Mickey. Martha and Bob. Mickey and Allen have become one of the "steady" couples seen about the campus this year, while Martha and Bob both go steady; but not with each other. They are enjoying the sunshine in front of "Old Main." This is quite a popular pastime with students who "never have anything to do."

T $\mathrm{H} \quad \mathrm{I} \quad \mathrm{S}$

I S

C

E D

A

R V

V

I

L I


1. Mixer - To start the year right, and to get acquainted with everyone, the Y. M. and Y. W. sponsored a mixer at the gym. We all enjoyed square dances and folk games with freshman Jean Ferguson officiating at the piano. The Virginia Reel was enjoyed by everyonebut the prize of the evening went to the coach. $\mathrm{He}$ not only enjoyed himself, but kept the rest of us amused.

2. The Pajama Parade-Always an exciting event, it was an activity of the year which the girls will never forget. First there's the excitement of slipping out in the dead of night, then attempted serenades, exploration of back alleys, and a plentiful supply of cold water from unexpected directions. Rumor said that Bea Williams even explored a horse trough in the vicinity of Hartman's during the evening.

3. In the Fall, the Faculty gave a reception for students of the college and their parents. During the evening the Cedarville College Orchestra under the direction of Mr. Bass appeared in public for the first time. The Orchestra presented several numbers which were very well received. Doris Williams sang, Mr. Bass played a violin solo, Miss Basore gave some readings and Wanda Hughes, Mrs. Reinhard, and Pres. Kilpatrick gave short speeches.

4. Hallowe'en Party - At the time of ghosts and witches and things, the churches went together to give the college one of the best parties of the year. Everyone came all masked, and after parading in front of the judges prizes were given for best costumes. The decorations consisted of lots of corn shocks, pumpkins, and other things suitable for Hallowe'en. Games were enjoyed by everyone, and appropriate refreshments were served.
5. The Chi Mu Delta Fraternity sponsored a "V for Victory" Dance at Alford Memorial Gym. The boys carried out the patriotic theme in their red, white, and blue decorations with large flags at both end of the gym. The grand march, during which the frat Greek letters were formed, ended in a large $\mathrm{V}$ and a salute to the flag. One of the most enjoyable dances of the year followed.

6. The Y. W. Thanksgiving Committal Service was held at the First Presbyterian Church with Pres. Orsadee Stewart presiding. Although this service is held yearly, it seems to take on a new significance each time. White dresses and candlelight add to the words of dedication and make the service remembered. Doris Williams and Dorothy Clark provided music for the evening and Mrs. Lenora MacMillan was accompanist. Readers were Bea O'Bryant and Rachel Neal.

7. The Y. W. girls held their Secret Pal Christmas Party at the Dorm. This event gives us an opportunity to become better acquainted with the wives of the faculty and of the ministers. Velma Henderson conducted an interesting "Truth or Consequences" quiz game, and we all enjoyed those refreshments which were left after the boys visited the kitchen secretly. Perhaps their visit accounts for the search for cars which followed.

8. We celebrated our first basketball victory of the year against Giffin at one of our first homes games with a triumphant snake dance led all over town by Layden "Buck" Wilson. The course ran through the various stores, lanes, and by-ways of the town as well as the main streets, and gradually wandered back to the club where the evening ended with dancing. 
9. The long-anticipated Home-coming was held on February 8 . About 250 quests enjoyed the banquet at which Rev. Dwight R. Guthrie was toastmaster and Mr. Ira Vayhinger and Pres. Walter S. Kilpatrick spoke. Doris Williams and Jean Ferguson delightfully entertained with music. A thrilling basketball game ended in a heartbreaking instance of historyrepeating when we lost by one point. Friendly chats and dancing brought that evening to a close.

10. During the year, two swimming parties were held at the Y. M. C. A. pool in Springfield. Many of the students attended the parties, and all enjoyed this unusual pleasure. For days afterwards several of the girls seemed to talk of nothing but the handsome lifeguard at the pool, but whether he or the sport formed the greater attraction, we all hope for more parties of this sort.

\section{The Y. W. St. Patrick's Buffet Luncheon} on Mar. 17 attracted many townspeople as well as faculty and students of the college. The success of the Luncheon was due to the efficient planning and capable management of our Social Chairman, Helen O'Bryant. Elleanor Young handled the publicity aspect with green shamrock posters, and the gym was appropriately decorated in green and white for the occasion by Laurel Diltz and her committee.

12. The Freshman Class sponsored a Hay Ride for the whole college on Mar. 26. Fred Lewis drove the large tractor which drew two wagons full of riders over the picturesque roads back of Cedarville. An unfortunate adventure in Yellow Springs proved that Ed. Weddle who had been following in his private "hay seed" was, contrary to expectations, a "sheep in wolf's clothing," and hero of the evening.
13. A bright highlight of the year was the Spring Semi-Formal Dance sponsored by the Chi Sigma Phi Sorority, which was held April 11, at the Gym. The evening found many of the Alumni back to renew friendships and to dance to the music of Cedric Adams and his orchestra from Springfield. The gym was beautifully decorated, and the evening is one which will long be remembered.

14. The Y. W. girls always look forward to the opportunity to entertain their mothers at the Mother-Daughter banquet which occurred this year on May 8. Our speaker was Chesta Fulmer, writer for the Dayton Herald. Orsadee Stewart presided, and introduced her cabinet as well as the officers for the next year to the mothers. Appropriate music was presented by the girls during the evening.

15. The Junior-Senior Banquet was held in Cedarville this year. A lovely dinner was served at the Methodist Church by the church women, and enjoyed by members of the two classes and their guests, and the faculty members and wives. After the banquet everyone who cared to, adjourned to the gym to spend the evening dancing. A patriotic scheme was used for the decorations. Lee Miller, head of Junior Class, had charge of the arrangements for the evening.

16. This year fifteen students of the college faced the final test of their college education by tackling the difficult problem of practice teaching. Eight girls in the elementary field each taught two different subjects in the public school during the second semester. Some of the High School teachers taught during the first semester, and some during the second. We wish all of them all the success in the world next year. 


\section{Memaries}

There are many things which go to make up the definition of college life. Many never occur in the classroom or even in the buildings, yet they will become a desired part of our memories. In this "Cedrus," the staff has tried to present in a pleasant and interesting way many things which will, in the future, become memories.

This year has been one of great importance in the lives of all of us. December 7, 1941, —War!! — "Remember Pearl Harbor" — "V for Victory" - All these and many more sayings bring us memories which we do not especially like, but which help us to realize the great task which lies before us. Some of us who appear in the story presented by the "Cedrus" may never see the end of this conflict, yet we will retain memories and appear in the memories of many of you.

There are many persons to whom credit is due for the success of this book. Each member of the staff plays an important part by doing his assigned task, no matter how small and unimportant it may seem. There is much which goes on behind the scenes and which is never known, but which helps to complete the work successfully.

Special credit should be given to three persons who have done a tremendous part of the work and who are comparatively unknown. Mr. William J. Freund, the representative of the Pontiac Engraving Co., who helped plan the book and then acted as general overseer till the completion of the job.

Mr. John A. West, the representative of the Greenfield Printing and Publishing Co., who also aided in the planning and gave many valuable suggestions as the work progressed.

Our own "Hal" Guthrie, who acted as official photographer and took most of the pictures which appear in the book. "Hal" deserves much praise for his untiring efforts to do things which would make this annual more interesting.

We must not forget, however, the persons whose advertisements appear in the "Cedrus." They are in reality good friends who have given us aid and helped us to make possible this book.

Thus have the combined efforts of many people gone to help give you memories which you will retain for many years to come.

The Editor

A

R

V

I I


Advertisements

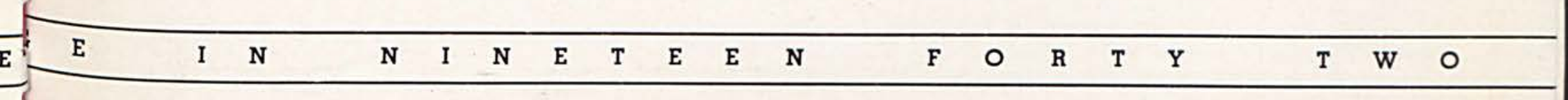




\section{Compliments of Your}

\section{Thrift - E - Market}

\section{GEDARVILLE, OHIO}

\section{QUALITY}

- FOODS

- MEATS

- FRESH FRUITS

- FRESH VEgETABLES 


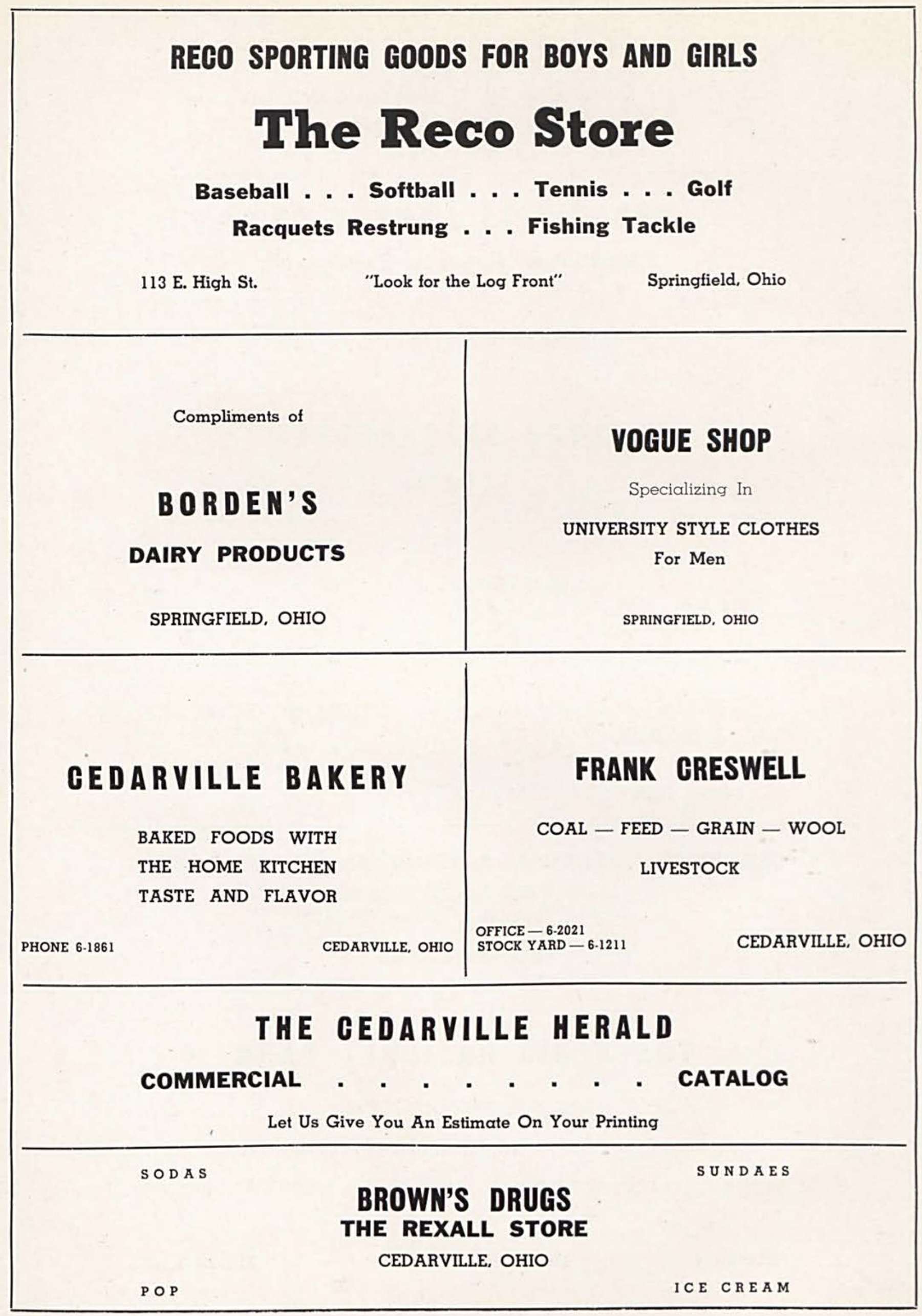


U CAN STRETCH UR \$ BY BUYING UR DRY GOODS, CLOTHING, SHOES, AND NOTIONS FROM US

Also the Best Auto Insurance and Quickest Service in Greene County

HOME CLOTHING COMPANY

G. H. HARTMAN, Prop.

\section{GEDARVILLE LUMBER GO. \\ International Harvester Implements}

PHONE 6-1331

CEDARVILLE, OHIO

\section{HILLTOP GREENHOUSES}

H. C. FENCKEL

PHONE 4-3311

JAMESTOWN, OHIO

FLOWERS FOR ALL OCCASIONS

Compliments of

R. J. BLACK

CANDIEES AND TOBACCOS

URBANA, OHIO

\begin{tabular}{|c|c|c|}
\hline \multicolumn{3}{|c|}{$\begin{array}{l}\text { "BERT" FARIS } \\
\text { STERLING JEWELRY }\end{array}$} \\
\hline \multirow{3}{*}{ WATCHES } & $\begin{array}{l}\text { CLASS RINGS AND JEWELRY } \\
\text { TROPHY HEADQUARTERS }\end{array}$ & - \\
\hline & AND & DIAMONDS \\
\hline & SPRINGFIELD, OHIO & \\
\hline
\end{tabular}

LOAN ASS'N.

MONEY TO LOAN ON REAL ESTATE

CEDARVILLE, OHIO

\section{THE XENIA NATIONAL BANK}

THIRD OLDEST BANKING ORGANIZATION IN THE STATE 


